\title{
Brachiopoda from the Gulf of Gascogne, France (Recent)
}

\section{G. ARTHUR COOPER}




\title{
SERIES PUBLICATIONS OF THE SMITHSONIAN INSTITUTION
}

Emphasis upon publication as a means of "diffusing knowledge" was expressed by the first Secretary of the Smithsonian. In his formal plan for the Institution, Joseph Henry outlined a program that included the following statement: "It is proposed to publish a series of reports, giving an account of the new discoveries in science, and of the changes made from year to year in all branches of knowledge." This theme of basic research has been adhered to through the years by thousands of titles issued in series publications under the Smithsonian imprint, commencing with Smithsonian Contributions to Knowledge in 1848 and continuing with the following active series:

\author{
Smithsonian Contributions to Anthropology \\ Smithsonian Contributions to Astrophysics \\ Smithsonian Contributions to Botany \\ Smithsonian Contributions to the Earth Sciences \\ Smithsonian Contributions to the Marine Sciences \\ Smithsonian Contributions to Paleobiology \\ Smithsonian Contributions to Zoology \\ Smithsonian Studies in Air and Space \\ Smithsonian Studies in History and Technology
}

In these series, the Institution publishes small papers and full-scale monographs that report the research and collections of its various museums and bureaux or of professional colleagues in the world of science and scholarship. The publications are distributed by mailing lists to libraries, universities, and similar institutions throughout the world.

Papers or monographs submitted for series publication are received by the Smithsonian Institution Press, subject to its own review for format and style, only through departments of the various Smithsonian museums or bureaux, where the manuscripts are given substantive review. Press requirements for manuscript and art preparation are outlined on the inside back cover.

\author{
S. Dillon Ripley \\ Secretary \\ Smithsonian Institution
}




\title{
Brachiopoda from the Gulf of Gascogne, France (Recent)
}

\author{
G. Arthur Cooper
}

SMITHSONIAN INSTITUTION PRESS

City of Washington

1981 


\section{A B S T R A C T}

Cooper, G. Arthur. Brachiopoda from the Gulf of Gascogne, France (Recent). Smithsonian Contributions to Paleobiology, number 44, 35 pages, 5 figures, 3 plates, 1981.-Brachiopods collected during the operations of Biogas and Polygas, Gulf of Gascogne Abyssal Survey, and Thalassa, Gulf of Gascogne Bathyal Survey of the Centre Océanologique de Bretagne, are recorded and data concerning them noted. Most of the specimens taken in Biogas and Polygas are from depths ranging from 1010 meters to 4459 meters. The specimens taken by Thalassa are mostly from waters less than 1000 meters in depth. Twenty-one species in 14 genera are recognized, six of them, including a new species, hitherto not recorded from the Gulf of Gascogne, are starred: *Pelagodiscus atlanticus (King), Crania anomala (Müller), C. anomala turbinata (Poli), ${ }^{*}$ Cryptopora gnomon Jeffreys, Hispanirhynchia cornea (Fischer), Eucalathis ergastica Fischer and Oehlert, E. tuberata (Jeffreys), Terebratulina retusa (Linné), T. retusa emarginata (Risso), Gryphus vitreus (Born), ${ }^{*} G$. ? cooperi d'Hondt, Dallithyris? aff. D.? sphenoidea (Jeffreys), Platidia anomioides (Scacchi and Philippi), Megerlia truncata (Linné), M. echinata (Fischer and Oehlert), Pantellaria monstruosa (Scacchi), Macandrevia cranium (Müller), ${ }^{*} M$. novangliae Dall, ${ }^{*}$ Fallax dalliniformis Atkins, Dallina septigera (Lovén), and ${ }^{*} D$. parva, new species. Five described species not previously recorded from the Gulf of Gascogne are: Pelagodiscus atlanticus (King), a world-wide abyssal form; Cryptopora gnomon (Jeffreys), widespread in the northern Atlantic; Macandrevia novangliae Dall, hitherto only known from deep water off the coast of New England, United States; Fallax dalliniformis Atkins, newly discovered in the approaches to the English Channel; and Gryphus? cooperi d'Hondt recently described. The first four were taken in deep water in the Biogas operations; the fifth was taken by Thalassa. Specimens taken by Thalassa are mostly small or immature forms that are usually difficult to identify generically. Specimens of the rare genus Eucalathis appeared in several lots taken by Thalassa as well as the new species, Dallina parva. Not included in the above lists is a fossil brachiopod, dredged by Thalassa, that is assigned with a query to the Cretaceous genus Meonia.

OfFICIAL PUBLICATION DATE is handstamped in a limited number of initial copies and is recorded in the Institution's annual report, Smithsonian Year. SERIEs COVER DEsign: The trilobite Phacops rana Green.

Library of Congress Cataloging in Publication Data

Cooper, G. Arthur

Brachiopoda from the Gulf of Gascogne, France (Recent)

(Smithsonian contributions to paleobiology; no. 44)

Bibliography: p.

1. Brachiopoda-Biscay, Bay of (France and Spain) I. Title. II. Series.

QE701.S56 no. 44 [QL395.3.B58] 560s 81-607040 [595.3'20944] AACR2 


\section{Contents}

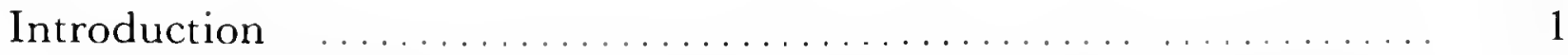

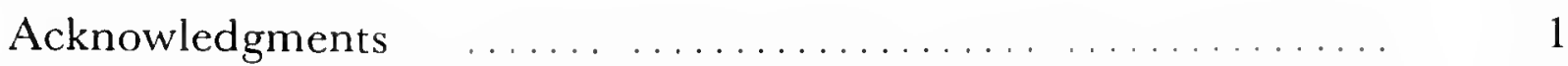

Previous Work in the Gulf of Gascogne $\ldots \ldots \ldots \ldots \ldots \ldots \ldots \ldots, \ldots \ldots$

Species Collected ..................................... 3

Brachiopods and Station Records, Biogas Cruises $\ldots \ldots \ldots \ldots \ldots . . \ldots$

Brachiopods and Station Records, Polygas Cruise $\ldots \ldots \ldots \ldots \ldots \ldots$

Brachiopods and Station Records, Thalassa Cruises ............... 5

Systematics (hierarchy from class through genus) . . ........... 7

Genus Pelagodiscus Dall, 1908 ......................... 8

Pelagodiscus atlanticus (King) .......................... 8

Genus Crania Retzius, 1781 .......................... 8

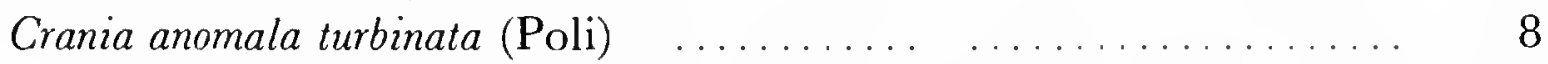

Crania anomala (Müller) ............................. 9

Genus Cryptopora Jeffreys, 1869 ........................ 9

Cryptopora gnomon Jeffreys $\ldots \ldots \ldots \ldots \ldots \ldots \ldots \ldots \ldots \ldots . \ldots \ldots$

Genus Hispanirhynchia Thomson, 1927 .................... $\quad 10$

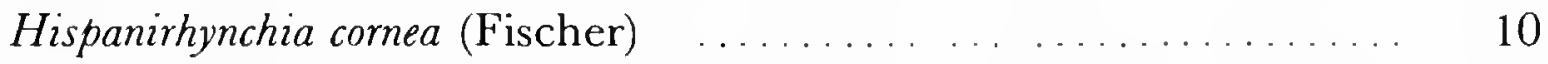

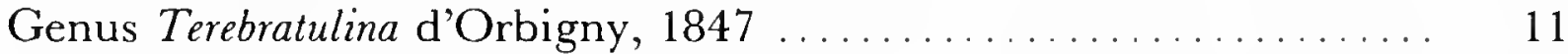

Terebratulina retusa emarginata (Risso) ...................... 11

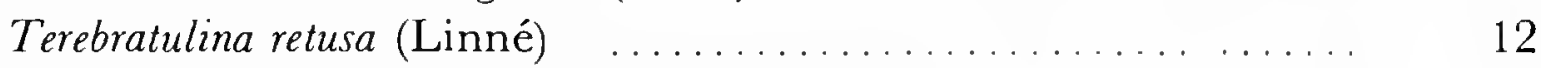

Genus Eucalathis Fischer and Oehlert, 1890 ................ 12

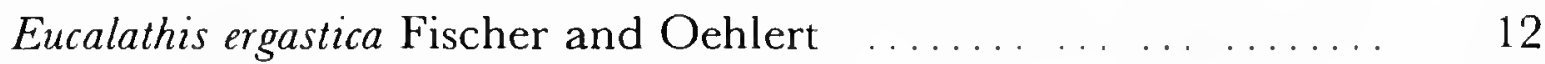

Eucalathis tuberata (Jeffreys)

Genus Meonia Steinich, 1963 ........................... 13

Meonia? species .................................... 13

Genus Gryphus Megerle von Mühlfeldt, 1811 ............... 13

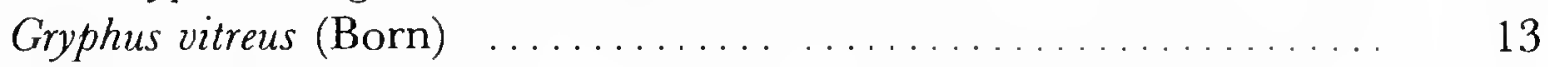

Gryphus? cooperi d'Hondt ............................. 14

Genus Dallithyris Muir-Wood, 1959 ...................... 15

Dallithyris? aff. D.? sphenoidea (Jeffreys) not Philippi ......... 15

Genus Platidia Costa, 1852 .......................... 16

Platidia anomioides (Scacchi and Philippi) ................ 16

Genus Megerlia King, $1850 \ldots \ldots \ldots \ldots \ldots \ldots \ldots \ldots \ldots \ldots \ldots \ldots$

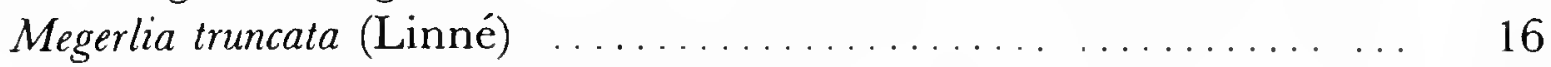

Megerlia echinata (Fischer and Oehlert) $\ldots \ldots \ldots \ldots \ldots \ldots \ldots . \ldots \ldots$

Genus Pantellaria Dall, 1919 ............................ 17

Pantellaria monstruosa (Scacchi) _......................... 17

Genus Macandrevia King, 1859 ...................... 17

Macandrevia cranium (Müller) $\ldots \ldots \ldots \ldots \ldots \ldots \ldots \ldots \ldots \ldots \ldots \ldots$

Macandrevia novangliae Dall $\ldots \ldots \ldots \ldots \ldots \ldots \ldots \ldots . \ldots \ldots$

iii 
Genus Fallax Atkins, 1960 ................................ 22

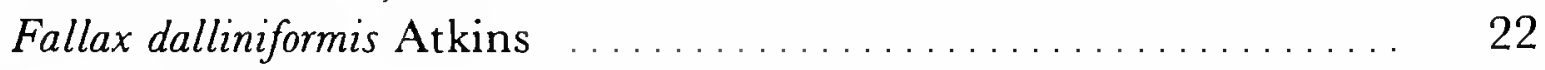

Genus Dallina Beecher, 1893 ......................... 23

Dallina septigera (Lovén) _......................... 23

Dallina parva, new species ........................ 24

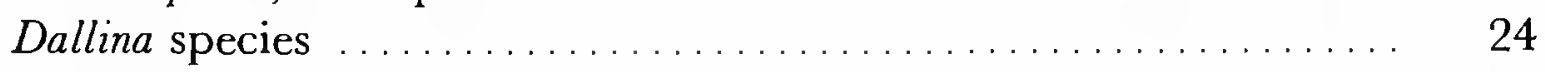

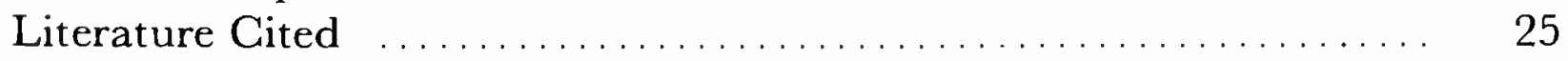

Plates ........................................... 29 


\section{Brachiopods from the Gulf of Gascogne, France (Recent)}

\section{G. Arthur Cooper}

\section{Introduction}

In late 1975 I was invited to examine and report on collections of modern brachiopods from the Gulf of Gascogne in the southern part of the Bay of Biscay. The specimens, consisting of 98 lots, were collected by vessels of the Centre Océanologique de Bretagne, Dr. M. Segonzac, Chief, in three programs: Biogas, which made seasonal studies of the deeps near Brest and near the northern coast of Spain; Polygas, which operated in the same areas; and Thalassa, which operated in shallower waters.

The Biogas project extended from 1972 to 1974 and was devoted to a study of the deep sea, its fauna, flora, and sediments. Seven cruises were conducted at different times of the year to evaluate the diversity and density of the inhabitants of the deeps and to study biological rhythms at each of several stations. Six stations were located on soft bottoms between 1800 and 4700 meters in the northwest and southeast parts of the Gulf (Figure 1). Each station was sampled several times at 3 to 5 month intervals with various types of oceanographic gear, each taking a different size category of the total fauna: the epibenthic sled, trawl, Reineck box corer, and baited trap.

G. Arthur Cooper, Department of Paleobiology, National Museum of Natural History, Smithsonian Institution, Washington, D. C. 20560.
Forty-six lots, including 4 from Polygas, were examined.

The Thalassa program was organized by the Biological Laboratory of Roscoff to study the faunas and conditions on the slope of the continental shelf of the Gulf of Gascogne. Most of this material, 50 lots, consist of young and very small brachiopods often difficult to identify because of the generalized interior details of the minute forms with just deposited shell. The specimens studied were sorted by Centob, the Centre National de Tri d'Océanographie Biologique located in Brest. Like the Sorting Center of the Smithsonian Institution, Centob distributes specimens for study to specialists all over the world (Laubier and Sibujet, 1977)

Figured and described specimens, deposited in the Muséum National d'Histoire Naturelle, Paris, are labelled MNHN-BRA-78, plus number.

ACKNOWLEDGMENTS.-I acknowledge with pleasure my obligation to Dr. Michel Segonzac, Chief of the Center, for making this study possible. I am also grateful to all those unseen and unknown-to-me skillful sorters who prepared the brachiopod samples. Those often included the tiniest, easily overlooked of young forms and obscure ones attached to pebbles.

Drs. J. Thomas Dutro, Jr. and Robert B. Neuman read the manuscript and offered good suggestions for its improvement. I am grateful to them for this help. 


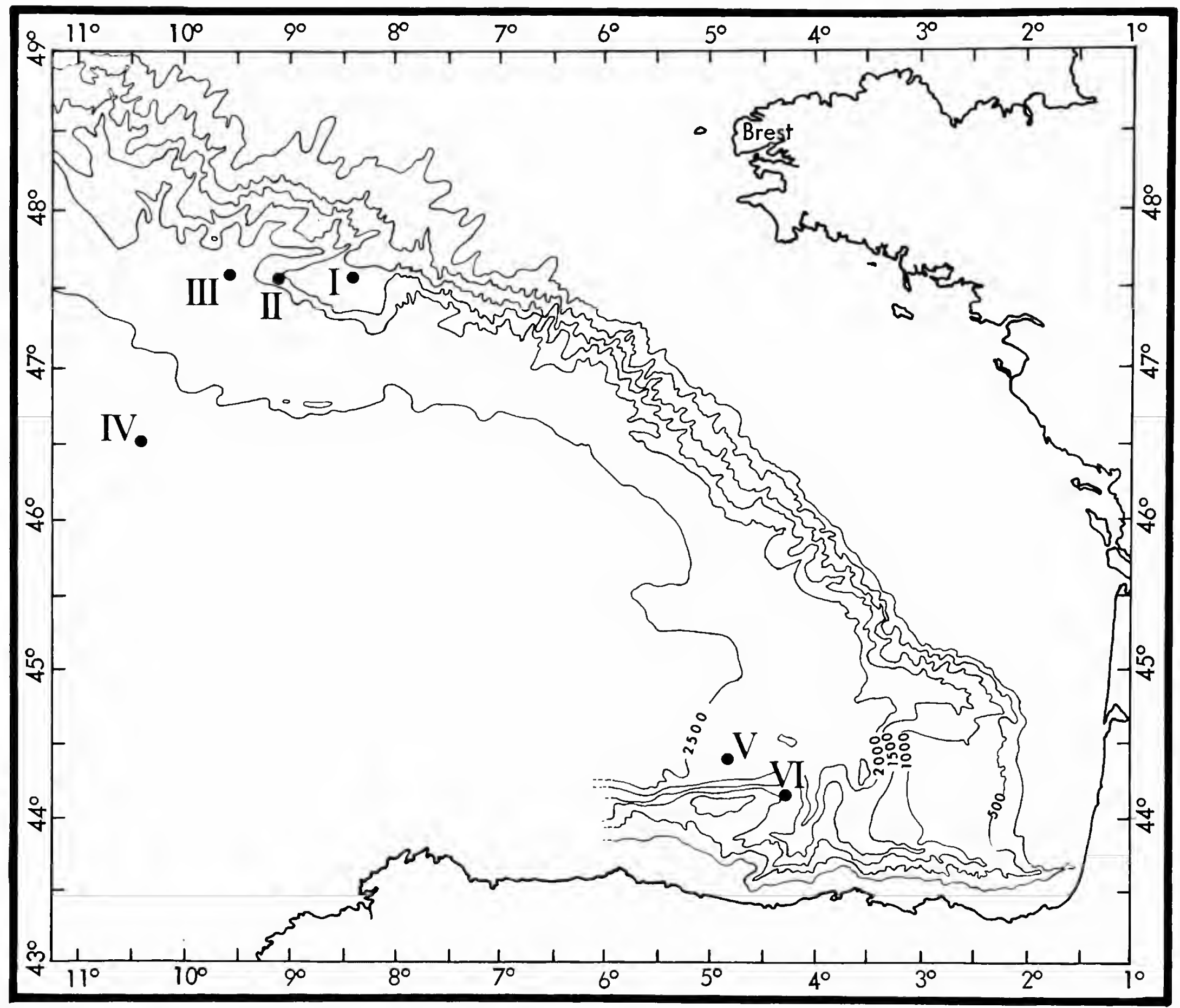

Figure 1.-Map of Gulf of Gascogne showing stations of Biogas I-VI.

\section{Previous Work in the Gulf of Gascogne}

During the "golden age" of oceanographic exploration in the latter half of the 19th century, the Gulf of Gascogne was subjected to intensive study. Several research ships, l'Hirondell belonging to Prince Albert of Monaco (list recorded by d'Hondt 1976:11) and the Talisman and Travailleur explored extensively in the Gulf. Considerable interest was taken in the brachiopods resulting from dredging operations of their cruises because of the geological and biological implications that would result from their study. The French scientists Paul Fischer and D. P. Oehlert (1892) prepared a large, handsome monograph summarizing the information on the Gulf of Gascogne brachiopods and those of adjacent Atlantic waters. These authors state: "At present [1892] the Gulf of Gascogne is, among all the seas of the globe, one of the richest in brachiopods." They list 16 species as follows: Crania anomala turbinata (Poli), Rhynchonella [Hispanirhynchia] cornea (Fischer), Dyscolia wyvillei (Davidson), Eucalathis tuberata (Jeffreys), E. ergastica Fischer and Oehlert, 
Terebratulina caput-serpentis [=retusa emarginata (Risso)] Linné, Terebratula [Gryphus] vitreus (Born), T. [Dallithyris?] sphenoidea (Philippi), Magellania [Dallina] septigera (Lovén), Macandrevia cranium (Müller), Mühlfeldtia [Megerlia] truncata (Linné), $M$. [P.] monstruosa Scacchi, Platidia anomioides (Scacchi and Philippi), P. davidsoni Deslongchamps, Megathyris decollata (Chemnitz), and Cistella [now Argyrotheca] cistellula (S. Wood). Specimens from the Gulf have recently been described by d'Hondt (1976).

Of the 21 species identified in the Biogas and Thalassa collections five do not appear in the above list and the last three of Fischer and Oehlert's list were not found during these modern dredging operations. Fischer and Oehlert (1892: 4) mention two other species of doubtful occurrence, the one Dyscolia subquadrata (Jeffreys) is the possible young of Dyscolia wyvillei (Davidson). The other is a single valve of Thecidea [now Lacazella] mediterranea ( $\mathrm{Risso}$ ). The latter is a common Mediterranean brachiopod and might be expected in the Gulf of Gascogne attached to coralline bodies as it is in the Mediterranean.

The six species not present in Fischer and Oehlert's list are: Pelagodiscus atlanticus (King), a nearly ubiquitous deep sea brachiopod; Cryptopora gnomon Jeffreys, Macandrevia novangliae Dall, Gryphus? coopern d'Hondt, Fallax dalliniformis Atkins, and Dallina parva, new species.

Macandrevia novangliae, hitherto only known from the waters off New England, is reported from European waters for the first time. The species of Fallax was only recently described (Atkins 1960a) from the approaches to the English Channel and is thus a likely occurrence in the Gulf of Gascogne. As mentioned below, some of the figures of Dallina septigera in Fischer and Oehlert (1891) belong to Fallax. The two genera are very closely related, Fallax being an arrested stage of Dallina. Gryphus? cooperi is an interesting small species with internal shell structures suggestive of relationship to Dyscolia.

Another Gulf of Gascogne species recorded by d'Hondt and not identified in the present work is Dyscolia wyvillei (Davidson), first found in the
Caribbean Sea, a very large brachiopod occurring in deep water. D'Hondt records Terebratulina septentrionalis (Couthouy) along with $T$. retusa (Linné). The former is common in eastern and north Atlantic waters and distinction between the two species is often difficult.

Explorations in the Bay of Biscay and Gulf of Gascogne are also reported by Fischer and Oehlert (1890b), Jeffreys (1880), and Joubin (1907).

\section{Species Collected}

(* Biogas, \#Polygas, !Thalassa)

\footnotetext{
Argyrotheca cistellula (S. Wood)

! Crania anomala (Müller)

*! C. anomala turbinata (Poli)

\#*! Cryptopora gnomon Jeffrey

! Dallina parva, new species

*! D. septigera (Lovén)

* Dallithyris? sphenoides (Jeffreys) not Philippi

Dyscolia wyvillei (Davidson)

*! Eucalathis ergastica Fischer and Oehlert

*! E. tuberata (Jeffreys)

* Fallax dalliniformis Atkins

! Gryphus? cooperi (d'Hondt)

* $G$. vitreus (Born)

*! Hispanirhynchia cornea (Fischer)

*! Macandrevia cranium (Müller)

\#* $M$. novangliae Dall

Megathiris decollata (Gmelin)

! Megerlia echinala (Fischer and Oehlert)

! M. truncala (Linné)

! Pantellaria monstruosa (Scacchi)

\#* Pelagodiscus allanticus (King)

*! Platidia anomioides (Scacchi and Philippi)

$P$. davidsoni Deslongchamps

! Terebratulina retusa (Linné)

*! T. relusa emarginala (Risso)
}

\section{Brachiopods and Station Records, Biogas Cruises}

\section{Biogas I}

DS 01 Latitude $47^{\circ} 55.8^{\prime} \mathrm{N}$, longitude $07^{\circ} 40^{\prime} \mathrm{W}$ at 310 meters

Crania anomala turbinata (Poli), 1

Terebratulina retusa emarginala (Risso), 15

Gryphus vitreus (Born), 55

Macandrevia cranium (Müller), 44 
CM 01 Latitude $47^{\circ} 44.3^{\prime} \mathrm{N}$, longitude $08^{\circ} 51^{\prime} \mathrm{W}$ at 1010 meters

Macandrevia cranium (Müller), 3

Dallina septigera (Lovén), 10

CW 01 Latitude $47^{\circ} 58.8^{\prime} \mathrm{N}$, longitude $07^{\circ} 40^{\prime} \mathrm{W}$ at 280 meters

Gryphus vilreus (Born), 19

Macandrevia cranium (Müller), 1

\section{BIOGAS II}

DS 33 Latitude $47^{\circ} 39.7^{\prime} \mathrm{N}$, longitude $08^{\circ} 05.5^{\prime} \mathrm{W}$ at 2338 meters

Hispanirhynchia cornea (Fischer), 6

Macandrevia novangliae Dall, 1

?Dallina sepligera (Lovén), 2

DS 34 Latitude $47^{\circ} 42.4^{\prime} \mathrm{N}$. longitude $08^{\circ} 03.4^{\prime} \mathrm{W}$ at 1031 meters

Dallina septigera (Lovén), 1

CV 21 Latitude $47^{\circ} 42.5^{\prime} \mathrm{N}$, longitude $08^{\circ} 03.2^{\prime} \mathrm{W}$ at 994 meters

Hispanirhynchia cornea (Fischer), 2

Macandrevia cranium (Müller), 2

Dallina sepligera (Lovén), 16

\section{Biogas III}

DS 42 Latitude $47^{\circ} 32.1^{\prime} \mathrm{N}$, longitude $09^{\circ} 35.6^{\prime} \mathrm{W}$ at 4104 meters

Pelagodiscus allanticus (King), 1

CV 22 Latitude $47^{\circ} 41.8^{\prime} \mathrm{N}$, longitude $08^{\circ} 18.7^{\prime} \mathrm{W}$ at 1331 meters

Hispanirhynchia cornea (Fischer), 12

Dallithyris? aff. D.? sphenoidea (Jeffreys), not Philippi, 1

Fallax dalliniformis Atkins, 2

Macandrevia novangliae Dall, 1

CV 23 Latitude $42^{\circ} 32.7^{\prime} \mathrm{N}$, longitude $08^{\circ} 34.2^{\prime} \mathrm{W}$ at 2034 meters

Macandrevia novangliae Dall, 1

CV 24 Latitude $47^{\circ} 33.7^{\prime} \mathrm{N}$, longitude $08^{\circ} 34.3^{\prime} \mathrm{W}$ at 2025 meters

Macandrevia novangliae Dall, 1

CV 32 Latitude $44^{\circ} 07.6^{\prime} \mathrm{N}$, longitude $04^{\circ} 15.8^{\prime} \mathrm{W}$ at 1895 meters

Macandrevia novangliae Dall, 2

\section{Biogas IV}

DS 52 Latitude $44^{\circ} 06.3^{\prime} \mathrm{N}$, longitude $04^{\circ} 22.4^{\prime} \mathrm{W}$ at 2006 meters

Pelagodiscus allanticus (King), 1

Dallina species, probably young of Dallina sepligera (Lovén), 3
DS 53 Latitude $44^{\circ} 30.4^{\prime} \mathrm{N}$, longitude $04^{\circ} 56.3^{\prime} \mathrm{W}$ at 4425 meters

Pelagodiscus allanticus (King), 1

DS 55 Latitude $47^{\circ} 34.9^{\prime} \mathrm{N}$, longitude $09^{\circ} 40.9^{\prime} \mathrm{W}$ at 4125 meters

Pelagodiscus allanticus (King), 1

DS 57 Latitude $47^{\circ} 30.8^{\prime} \mathrm{N}$, longitude $09^{\circ} 07.6^{\prime} \mathrm{W}$ at 2906 meters

Pelagodiscus allanticus (King), 47

DS 58 Latitude $47^{\circ} 34.1^{\prime} \mathrm{N}$, longitude $09^{\circ} 08.2^{\prime} \mathrm{W}$ at 2775 meters

Pelagodiscus allanticus (King), 1

DS 62 Latitude $47^{\circ} 32.8^{\prime} \mathrm{N}$, longitude $08^{\circ} 40^{\prime} \mathrm{W}$ at 2175 meters

Dallina species, young of $D$. sepligera (Lovén)

DS 63 Latitude $47^{\circ} 32.8^{\prime} \mathrm{N}$, longitude $08^{\circ} 35^{\prime} \mathrm{W}$ at 2126 meters

Pelagodiscus allanticus (King), 2

DS 64 Latitude $47^{\circ} 29.2^{\prime} \mathrm{N}$, longitude $08^{\circ} 30.7^{\prime} \mathrm{W}$ at 2156 meters

Pelagodiscus allanticus (King), 2

CV 36 Latitude $47^{\circ} 34.1^{\prime} \mathrm{N}$, longitude $09^{\circ} 38.5^{\prime} \mathrm{W}$ at 4209 meters

Pelagodiscus allanlicus (King), 1

CV 37 Latitude $47^{\circ} 33.5^{\prime} \mathrm{N}$, longitude $09^{\circ} 14^{\prime} \mathrm{W}$ at 3000 meters

Pelagodiscus allanticus (King), 7

CV 38 Latitude $47^{\circ} 30.9^{\prime} \mathrm{N}$, longitude $08^{\circ} 59.5^{\prime} \mathrm{W}$ at 2695 meters

Pelagodiscus allanticus (King), 2

CP 01 Latitude $47^{\circ} 34.6^{\prime} \mathrm{N}$, longitude $08^{\circ} 38.8^{\prime} \mathrm{W}$ at 2245 meters

Pelagodiscus allanticus (King), 1

CP 03 Latitude $47^{\circ} 32.7^{\prime} \mathrm{N}$, longitude $08^{\circ} 34^{\prime} \mathrm{W}$ at 2119 meters

Macandrevia novangliae Dall, 1

\section{Biogas V}

CP 07 Latitude $44^{\circ} 09.8^{\prime} \mathrm{N}$, longitude $04^{\circ} 16.4^{\prime} \mathrm{W}$ at 2170 meters

? Gryphus vilreus (Born) fragment, 1

Macandrevia novangliae Dall, 85

KR 45 Latitude $47^{\circ} 33.5^{\prime} \mathrm{N}$, longitude $09^{\circ} 05.5^{\prime} \mathrm{W}$ at 2864 meters

Crypiopora gnomon Jeffreys, 1

\section{Biogas VI}

DS 71 Latitude $47^{\circ} 34.3^{\prime} \mathrm{N}$, longitude $08^{\circ} 33.8^{\prime} \mathrm{W}$ at 2194 meters

Pelagodiscus allanticus (King), 1

DS 72 Latitude $47^{\circ} 38.6^{\prime} \mathrm{N}$, longitude $08^{\circ} 36.1^{\prime} \mathrm{W}$ at 2250 meters

Pelagodiscus allanticus (King), 2 
DS 74 Latitude $47^{\circ} 33^{\prime} \mathrm{N}$, longitude $09^{\circ} 07.8^{\prime} \mathrm{W}$ at 2777 meters

Pelagodiscus atlanticus (King), 2

Cryptopora gnomon Jeffrey, 1

DS 87 Latitude $44^{\circ} 05.2^{\prime} \mathrm{N}$, longitude $04^{\circ} 19.4^{\prime} \mathrm{W}$ at 1913 meters

Cryptopora gnomon Jeffreys, 1

CP 08 Latitude $44^{\circ} 33.2^{\prime} \mathrm{N}$, longitude $08^{\circ} 38.5^{\prime} \mathrm{W}$ at 2177 meters

Pelagodiscus atlanticus (King), 1

CP 09 Latitude $47^{\circ} 33^{\prime} \mathrm{N}$, longitude $08^{\circ} 44.1^{\prime} \mathrm{W}$ at 2171 meters

Macandrevia novangliae Dall, 1

CP 10 Latitude $47^{\circ} 29.6^{\prime} \mathrm{N}$, longitude $09^{\circ} 04.5^{\prime} \mathrm{W}$ at 2878 meters

Pelagodiscus atlanticus (King), 44

CP 11 Latitude $47^{\circ} 30^{\prime} \mathrm{N}$, longitude $09^{\circ} 07.4^{\prime} \mathrm{W}$ at 3056 meters

Pelagodiscus atlanticus (King), 17

CP 13 Latitude $47^{\circ} 34.4^{\prime} \mathrm{N}$, longitude $09^{\circ} 38^{\prime} \mathrm{W}$ at 4134 meters

Pelagodiscus atlanticus (King), 7

CP 14 Latitude $47^{\circ} 32^{\prime} \mathrm{N}$, longitude $09^{\circ} 35.9^{\prime} \mathrm{W}$ at 4237 meters

Pelagodiscus atlanticus (King), 92

CP 16 Latitude $46^{\circ} 27.3^{\prime} \mathrm{N}$, longitude $10^{\circ} 25.8^{\prime} \mathrm{W}$ at 4825 meters

Pelagodiscus atlanticus (King), 2

CP 17 Latitude $46^{\circ} 30.8^{\prime} \mathrm{N}$, longitude $10^{\circ} 19.5^{\prime} \mathrm{W}$ at 4706 meters

Pelagodiscus atlanticus (King), 22

CP 19 Latitude $44^{\circ} 24.9^{\prime} \mathrm{N}$, longitude $04^{\circ} 51.3^{\prime} \mathrm{W}$ at 4434 meters

Pelagodiscus atlanticus (King), 1

CP 20 Latitude $44^{\circ} 23.2^{\prime} \mathrm{N}$, longitude $04^{\circ} 51.4^{\prime} \mathrm{W}$ at 4459 meters

Pelagodiscus atlanticus (King), 1

CP 23 Latitude $44^{\circ} 04.6^{\prime} \mathrm{N}$, longitude $04^{\circ} 21.4^{\prime} \mathrm{W}$ at 1980 meters

Pelagodiscus atlanticus (King), 1

Macandrevia novangliae Dall, 1

\section{Brachiopods and Station Records, Polygas Cruises}

DS 26 Latitude $44^{\circ} 08.2^{\prime} \mathrm{N}$, longitude $04^{\circ} 15^{\prime} \mathrm{W}$ at 2076 meters

Cryptopora gnomon Jeffreys, 1

CV 10 Latitude $47^{\circ} 30.7^{\prime} \mathrm{N}$, longitude $08^{\circ} 40.6^{\prime} \mathrm{W}$ at 2108 meters

Macandrevia novangliae Dall, 1

CP 11 Latitude $47^{\circ} 29.1^{\prime} \mathrm{N}$, longitude $08^{\circ} 16.1^{\prime} \mathrm{W}$ at 2141 meters

Macandrevia novangliae Dall, 1
CV 13 Latitude $47^{\circ} 31.8^{\prime} \mathrm{N}$, longitude $09^{\circ} 34.2^{\prime} \mathrm{W}$ at 4252 meters

Pelagodiscus atlanticus (King), 1

\section{Brachiopods and Station Records, Thalassa Cruises}

\section{Thalassa ${ }^{\prime} 70$}

W353 Latitude $43^{\circ} 39.2^{\prime} \mathrm{N}$, longitude $01^{\circ} 56.4^{\prime} \mathrm{W}$ at 380 meters

Crushed, unidentifiable, 1

W355 Latitude $43^{\circ} 42.1^{\prime} \mathrm{N}$, longitude $01^{\circ} 35.6^{\prime} \mathrm{W}$ to $43^{\circ} 42.2^{\prime} \mathrm{N}, 01^{\circ} 36.0^{\prime} \mathrm{W}$ at 1000 meters

Terebratulina retusa (Linné), young, 1

Megerlia echinata (Fischer and Oehlert), 1

W368 Latitude $43^{\circ} 36.9^{\prime} \mathrm{N}$, longitude $03^{\circ} 36.4^{\prime} \mathrm{W}$ at 400 137 meters

Crania anomala (Müller), 2

Terebratulina retusa (Linné), 3

Megerlia truncata (Linné), 2

W369 Latitude $43^{\circ} 37.0^{\prime} \mathrm{N}$, longitude $03^{\circ} 34.9^{\prime} \mathrm{W}$ at 1040 580 meters

Eucalathis ergastica Fischer and Oehlert, 1

\section{Thalassa '71}

X305 Latitude $44^{\circ} 05.0^{\prime} \mathrm{N}$, longitude $05^{\circ} 00.6^{\prime} \mathrm{W}$ to $05^{\circ} 00.3^{\prime} \mathrm{W}$ at $463 \mathrm{~m}$

Macandrevia cranium (Müller), 1 plus 3 ?

X312 Latitude $44^{\circ} 04.8^{\prime} \mathrm{N}$, longitude $04^{\circ} 55^{\prime} \mathrm{W}$ to $44^{\circ} 04.7$ $\mathrm{N}, 04^{\circ} 55.0^{\prime} \mathrm{W}$ at $490-478$ meters

Terebratulina retusa (Linné), 1

Dallina species, very young, 1

X334 Latitude $44^{\circ} 10.4^{\prime} \mathrm{N}$, longitude $04^{\circ} 51.0^{\prime} \mathrm{W}$ to $44^{\circ} 10^{\prime}$ $\mathrm{N}, 04^{\circ} 53.7^{\prime} \mathrm{W}$ at $1940-1870$ meters

Cryptopora gnomon Jeffreys, 1

X340 Latitude $44^{\circ} 07.0^{\prime} \mathrm{N}$, longitude $04^{\circ} 29.8^{\prime} \mathrm{W}$ to $44^{\circ} 06.9^{\prime} \mathrm{N}, 04^{\circ} 29.6^{\prime} \mathrm{W}$ at $860-910$ meters

Eucalathis tuberata (Jeffreys), 1

Terebratulina retusa (Linné), 1

Macandrevia cranium (Müller), 1

Dallina parva, new species, 58

X341 Latitude $44^{\circ} 07.2^{\prime} \mathrm{N}$, longitude $4^{\circ} 30.0^{\prime} \mathrm{W}$ to $44^{\circ} 07.3^{\prime} \mathrm{N}, 04^{\circ} 30.7^{\prime} \mathrm{W}$ at $840-800$ meters

Gryphus species, young (crushed), 1

Dallina septigera (Lovén), 3

?Unidentifiable young, 1

X342 Latitude $44^{\circ} 07.5^{\prime} \mathrm{N}$, longitude $04^{\circ} 36.2^{\prime} \mathrm{W}$ to $44^{\circ} 0.7 .7^{\prime} \mathrm{N}, 04^{\circ} 36.8^{\prime} \mathrm{W}$ at 700 meters

Platidia anomioides (Scacchi and Philippi), 1

Dallina species, young, 3

X343 Latitude $44^{\circ} 07.0^{\prime} \mathrm{N}$, longitude $04^{\circ} 38.8^{\prime} \mathrm{W}$ to $44^{\circ} 07.8^{\prime} \mathrm{N}, 04^{\circ} 38.9^{\prime} \mathrm{W}$ at $600-655$ meters 
Dallina species, very young, 2

X345 Latitude $44^{\circ} 06.2^{\prime} \mathrm{N}$, longitude $04^{\circ} 41.0^{\prime} \mathrm{W}$ to $44^{\circ} 06.7^{\prime} \mathrm{N}, 04^{\circ} 41.1^{\prime} \mathrm{W}$ at $525-550$ meters

Dallina species, very young, 2

X347 Latitude $44^{\circ} 07.3^{\prime} \mathrm{N}$, longitude $04^{\circ} 44.0^{\prime} \mathrm{W}$ to $44^{\circ} 07.4^{\prime} \mathrm{N}, 04^{\circ} 44.0^{\prime} \mathrm{W}$ at $640-910$ meters

Platidia anomioides (Scacchi and Philippi), 2

Dallina species, young, 4

X348 Latitude $44^{\circ} 07.5^{\prime} \mathrm{N}$, longitude $04^{\circ} 43.6^{\prime} \mathrm{W}$ to $44^{\circ} 07.4^{\prime} \mathrm{N}, 04^{\circ} 43.6^{\prime} \mathrm{W}$ at $900-600$ meters

Terebralulina relusa (Linné), 1

Eucalathis tuberata (Jeffreys), 3

Dallina species, young, 3

X352 Latitude $44^{\circ} 06.5^{\prime} \mathrm{N}$, longitude $04^{\circ} 45.2^{\prime}$ to $44^{\circ} 06.6^{\prime}$ $\mathrm{N}, 04^{\circ} 45.0^{\prime} \mathrm{W}$ at $580-545$ meters

Crania anomala (Müller), young, 1

Terebralulina retusa (Linné), 1

Gryphus?' cooperi d'Hondt, 1

Platidia anomioides (Scacchi and Philippi), 3

Pantellaria monstruosa (Scacchi), 5

Dallina species, young

X353 Latitude $44^{\circ} 06.8^{\prime} \mathrm{N}$, longitude $04^{\circ} 45.1^{\prime} \mathrm{W}$ at 655 635 meters

Eucalathis tuberala (Jeffreys), 1

Dallina species, young, 3

X360 Latitude $44^{\circ} 05.4^{\prime} \mathrm{N}$, longitude $04^{\circ} 49.6^{\prime} \mathrm{W}$ to $44^{\circ} 05.5^{\prime} \mathrm{N}, 04^{\circ} 49.7^{\prime} \mathrm{W}$ at $595-580$ meters

Terebralulina relusa (Linné), very young, 1

\section{Thalassa '72}

Y393 Latitude $41^{\circ} 20.6^{\prime} \mathrm{N}$, longitude $09^{\circ} 10.8^{\prime} \mathrm{W}$ at 820 meters

Small, unidentifiable ventral valve, 1

Y395 Latitude $41^{\circ} 19.4^{\prime} \mathrm{N}$, longitude $09^{\circ} 14.4^{\prime} \mathrm{W}$ at 810 meters

Platidia species, crushed, 1

Dallina? species, 1

Y396 Latitude $41^{\circ} 17.4^{\prime} \mathrm{N}$, longitude $09^{\circ} 15.7^{\prime} \mathrm{W}$ at 900 meters

Terebralulina retusa (Linné), 1

Y401 Latitude $40^{\circ} 36.8^{\prime} \mathrm{N}$, longitude $09^{\circ} 21.5^{\prime} \mathrm{W}$, no depth given

Dallina? species, very young, 1

Y407 Latitude $40^{\circ} 33.5^{\prime} \mathrm{N}$, longitude $09^{\circ} 24.0^{\prime} \mathrm{W}$ at 740 meters

Meonia? species, a fossil specimen, 1

\section{Thalassa ${ }^{\prime} 73$}

Z392 Latitude $47^{\circ} 34.9^{\prime} \mathrm{N}$, longitude $07^{\circ} 01.3^{\prime} \mathrm{W}$ at 390 meters

Terebralulina relusa emarginata (Risso), 3

Macandrevia species, young, 1

Dallina species, young, 7
Z393

Latitude $47^{\circ} 33.0^{\prime} \mathrm{N}$, longitude $07^{\circ} 04.7^{\prime} \mathrm{W}$ at 750 meters

Eucalathis ergastica Fischer and Oehlert, 1

Z394 Latitude $47^{\circ} 32.4^{\prime} \mathrm{N}$, longitude $07^{\circ} 06.8^{\prime} \mathrm{W}$ at 900 meters

Eucalathis tuberala (Jeffreys), 4

Macandrevia species young, 1

Z397 Latitude $47^{\circ} 33.8^{\prime} \mathrm{N}$, longitude $07^{\circ} 12.6^{\prime} \mathrm{W}$ at 511 meters

Terebralulina relusa emarginala (Risso), 3

Macandrevia species, young, 4

Z398 Latitude $47^{\circ} 36.0^{\prime} \mathrm{N}$, longitude $07^{\circ} 16.8^{\prime} \mathrm{W}$ at 830 meters

Crania anomala turbinata (Poli), young, 3

Terebratulina relusa emarginata ( $\mathrm{Risso}$ ), 9

Gryphus vilreus (Born), young, 1

Macandrevia species, young, 1

Z399 Latitude $47^{\circ} 34.8^{\prime} \mathrm{N}$, longitude $07^{\circ} 18.1^{\prime} \mathrm{W}$ at 825 meters

Gryphus vilreus (Born), young, 3

Platidia anomioides (Scacchi and Philippi), 2

Macandrevia species, young, 2

Z402 Latitude $47^{\circ} 39.5^{\prime} \mathrm{N}$, longitude $07^{\circ} 28.5^{\prime} \mathrm{W}$ at 450 meters

Terebralulina retusa emarginala ( $\mathrm{Risso}$ ), 2

Gryphus vitreus (Born), young, 1

Platidia anomioides (Scacchi and Philippi), 1

Z406 Latitude $47^{\circ} 44.4^{\prime} \mathrm{N}$, longitude $08^{\circ} 04.2^{\prime} \mathrm{W}$ at 1055 meters

Dallina species, young, 1

Z407 Latitude $47^{\circ} 43.6^{\prime} \mathrm{N}$, longitude $08^{\circ} 07.5^{\prime} \mathrm{W}$ to $47^{\circ} 45.2^{\prime} \mathrm{N}, 08^{\circ} 06.7^{\prime} \mathrm{W}$ at $1085-1115$ meters

Macandrevia species, young, 2

Z409 Latitude $47^{\circ} 43.1^{\prime} \mathrm{N}$, longitude $08^{\circ} 04.0^{\prime} \mathrm{W}$ to $47^{\circ} 42.9^{\prime} \mathrm{N}, 08^{\circ} 00.9^{\prime} \mathrm{W}$ at $1035-1080$ meters

Eucalathis ergastica Fischer and Oehlert, 2

Macandrevia cranium (Müller), 9

Dallina septigera (Lovén), 12

Z410 Latitude $47^{\circ} 50.7^{\prime} \mathrm{N}$, longitude $08^{\circ} 09.3^{\prime} \mathrm{W}$ at 1180 meters

Hispanirhynchia cornea (Fischer), young, 3

Eucalathis tuberala (Jeffreys), 2

Macandrevia species, young, 1

Dallina septigera (Lovén), 1

Z413 Latitude $48^{\circ} 03.1^{\prime} \mathrm{N}$, longitude $08^{\circ} 29.4^{\prime} \mathrm{W}$ at 805 meters

Crania anomala turbinala (Poli), young, 1

Hispanirhynchia cornea (Fischer), 2

Eucalathis species, young, cf. E. ergastica

Fischer and Oehlert, 4

Platidia anomioides (Scacchi and Philippi), 15

Macandrevia species, young, 1

Dallina species, young, 78 
Z414 Latitude $48^{\circ} 05.0^{\prime} \mathrm{N}$, longitude $08^{\circ} 29.8^{\prime} \mathrm{W}$ at 650 meters

Platidia anomioides (Scacchi and Philippi), 1

Gryphus vitreus (Born), young, 1

Eucalathis species, young, cf. E. ergastica Fischer and Oehlert, 1

Dallina species, young, 35

Z415 Latitude $48^{\circ} 07.2^{\prime} \mathrm{N}$, longitude $08^{\circ} 26.2^{\prime} \mathrm{W}$ at 380 meters

Platidia anomioides (Scacchi and Philippi), 1

Dallina species, young, 1

Z416 Latitude $48^{\circ} 13.5^{\prime} \mathrm{N}$, longitude $09^{\circ} 07.5^{\prime} \mathrm{W}$ at 480 meters

Macandrevia species, young, 1

Z417 Latitude $48^{\circ} 12.0^{\prime} \mathrm{N}$, longitude $09^{\circ} 09.5^{\prime} \mathrm{W}$ at 865 meters

Platidia anomioides (Scacchi and Philippi), 1

Macandrevia species, young, 14

Dallina species, young, 1

Z421 Latitude $48^{\circ} 22.5^{\prime} \mathrm{N}$, longitude $09^{\circ} 33.5^{\prime} \mathrm{W}$ at 950 meters

Macandrevia species, young, 3

Dallina species, young, 4

Z424 Latitude $48^{\circ} 27.9^{\prime} \mathrm{N}$, longitude $09^{\circ} 44.3^{\prime} \mathrm{W}$ at 475 meters

Terebratulina retusa emarginata ( $\mathrm{R}$ isso), young, 1

Z425 Latitude $48^{\circ} 27.9^{\prime} \mathrm{N}$, longitude $09^{\circ} 44.0^{\prime} \mathrm{W}$ at 700 meters

Dallina species, young, 1

Z427 Latitude $48^{\circ} 27.0^{\prime} \mathrm{N}$, longitude $09^{\circ} 48.4^{\prime} \mathrm{W}$ at 330 meters

Terebralulina retusa emarginata ( $\mathrm{Risso}$ ), young, 1

Macandrevia species, young, 1

Z430 Latitude $48^{\circ} 37.0^{\prime} \mathrm{N}$, longitude $09^{\circ} 52.2^{\prime} \mathrm{W}$ at 1080 meters

Hispanirhynchia cornea (Fischer), young, 1

Macandrevia species, young, 1

Z431 Latitude $48^{\circ} 38.2^{\prime} \mathrm{N}$, longitude $09^{\circ} 47.3^{\prime} \mathrm{W}$ at 800 meters

Platidia anomioides (Scacchi and Philippi), young, 1

Macandrevia species, young, 4

Z435 Latitude $48^{\circ} 39.7^{\prime} \mathrm{N}$, longitude $09^{\circ} 53.2 \mathrm{~W}$ at 1050 meters

Hispanirhynchia comea (Fischer), young, 5

Eucalathis ergastica Fischer and Oehlert, 38

Platidia anomioides (Scacchi and Philippi), 2

Dallina septigera (Loven), young and adult, 44

Z436 Latitude $48^{\circ} 39.8$, longitude $09^{\circ} 56.4^{\prime} \mathrm{W}$ at 1210 meters

Terebratulina retusa emarginata (Risso), 1

Macandrevia species, young, 1

Z437 Latitude $48^{\circ} 35.0^{\prime} \mathrm{N}$, longitude $10^{\circ} 23.7^{\prime} \mathrm{W}$ at 610 meters
Macandrevia cranium (Müller), 3

Z447 Latitude $48^{\circ} 47.3^{\prime} \mathrm{N}$, longitude $11^{\circ} 12.0^{\prime} \mathrm{W}$ to $48^{\circ} 47.4^{\prime} \mathrm{N}, 11^{\circ} 14.3^{\prime} \mathrm{W}$ at $1430-1550$ meters

Hispanirhynchia comea (Fischer), young, 2

Z450 Latitude $48^{\circ} 40.0^{\prime} \mathrm{N}$, longitude $10^{\circ} 36.1^{\prime} \mathrm{W}$ at 1170 meters

Specimens too small to identify accurately, may be young of Hispanirhynchia cornea (Fischer), 2

Z459 Latitude $48^{\circ} 37.3^{\prime} \mathrm{N}$, longitude $09^{\circ} 53.0^{\prime} \mathrm{W}$ at 1180 meters

Hispanirhynchia cornea (Fischer), young, 1

Macandrevia species, young, 3

\section{Systematics}

(hierarchy from class through genus)

Class Inarticulata Huxley, 1869

Order Acrotretida Kuhn, 1949

Suborder Acrotretidina Kuhn, 1949

Superfamily Discinacea Gray, 1840

Family Discinidae Gray, 1840

Subfamily Disciniscinae Schuchert and Levene, 1929

Genus Pelagodiscus Dall, 1908

Suborder Craniodina Waagen, 1885

Superfamily Craniacea Menke, 1828

Family Cranildae Menke, 1828

Genus Crania Retzius, 1781

Class Articulata Huxley, 1869

Order Rhynchonellida Kuhn, 1949

Superfamily Rhynchonellacea Gray, 1848

Family Cryptoporidae Muir-Wood, 1955

Genus Cryptopora Jeffreys, 1869

Family Frieleildae Cooper, 1959

Genus Hispanirhynchia Thomson, 1927

Order Terebratulida Waagen, 1883

Suborder Terebratulidina Waagen, 1883

Superfamily Cancellothyridace Thomson, 1926

Family Cancellothyrididae Thomson, 1926

Subfamily Cancellothyridinae Thomson, 1926

Genus Terebratulina d'Orbigny, 1847

Family Chlidonophoridae Muir-Wood, 1959

Subfamily Eucalathinae Muir-Wood, 1959

Genus Eucalathis Fischer and Oehlert, 1890

Genus Meonia Steinich, 1963

Superfamily Terebratulacea Gray, 1840

Family Terebratulidae Gray, 1840

Genus Gryphus Megerle von Mühlfeldt, 1811

Genus Dallithyris Muir-Wood, 1959

Suborder Terebratellidina Muir-Wood, 1955

Superfamily Terebratellacea King, 1850

Family Platidildae Thomson, 1927

Genus Platidia Costa, 1852 
Family Kraussinidae Dall, 1870

Genus Megerlia King, 1850

Genus Pantellaria Dall, 1919

Superfamily Dallinacea Beecher, 1893

Family Macandreviidae Cooper, 1973

Genus Macandrevia King, 1859

Family Dallinidae Beecher, 1893

Genus Fallax Atkins, 1960

Genus Dallina Beecher, 1893

\section{Genus Pelagodiscus Dall, 1908 \\ Pelagodiscus atlanticus (King)}

Plate 2: figures 39,40

Discina allantica King, 1868:170-173.—Dall, 1871:42.-Jeffreys, 1876:252; 1878:415._Davidson, 1880:62.

Discinisca atlantica (King).-Dall, 1873:177.-Davidson, 1888:200, pl. 26: figs. 18-22._Fischer and Oehlert, 1891: 120.

Pelagodiscus allanticus (King).-Dall, 1908:440.-Thomson, 1918:38, 40, 50._Dall, 1920:280.-Thomson, 1927:130, fig. 37.-Helmcke, 1940:313.-Hertlein and Grant, 1944: 21, pl. 2: figs. 1-5 [extensive reference list].-Zezina, 1965: 254-258.-Cooper, 1973b:10, pl. 5: fig. 36.-Foster, 1974: 39, fig. 13.-Cooper, 1977:52, pl. 1: figs. 8-13.

Description.-This is an easily recognized species because of its yellow to brown chitinous shell and marginal aureole of long, barbed setae. Its dorsal valve is conical in profile with the apex slightly posterior of the middle. The ventral valve is flat or concave and hidden from view. The outline is nearly circular or transversely elliptical and the shell is marked by irregular concentric lines of growth. The anterior slope is longer and less steep than that of the posterior. Setae are numerous and of different sizes, many of those of the dorsal valve equal or exceed the length of the shell. These long setae are confined to the sides and anterior of the shell, and are interspersed with shorter ones.

The ventral valve is flat or concave and marked posteriorly by a slit for the pedicle that is expanded into a circular form and is externally attached in a circular depression. The pedicle is short and the brachiopod adheres closely to hard objects, usually pebbles.

TyPEs.-Hypotypes: MNHN-BRA-78-54, -55.
Stations.-Biogas III, DS 42; Biogas IV, DS 52, DS 53, DS 55, DS 57, DS 58, DS 63, DS 64, CV 36, CV 37, CV 38, CP 01; Biogas VI, DS 71, DS 72, DS 74, CP 08, CP 10, CP 11, CP 13, CP 14, CP 16, CP 17, CP 19, CP 20, CP 23; Polygas, CV 13.

Discussion.-According to Dall (1920:280), this is the most cosmopolitan brachiopod known because it is found in all the deep seas of the world except the Arctic, throughout the Atlantic and Pacific oceans, the Antarctic, the Indian Ocean, the Caribbean Sea, and the Gulf of Mexico. In all these vast areas it is generally in the abyss. The shallowest record is off Fernandina, Florida, at 538 meters (Dall, 1920:280). Generally the depths are far greater than 1000 meters. The deepest record is 6100 meters (Zezina, 1970: 5). In the Gulf of Gascogne it was dredged from 2006 to 4825 meters.

\section{Genus Crania Retzius, 1781}

\section{Crania anomala turbinata (Poli)}

Plate 1: Figure 26

Anomia turbinata Poli, 1795:189, pl. 30; fig. 15.

Crania anomala var. turbinata (Poli)._-Dall, 1871:34._-Fischer and Oehlert, 1891:7, pl. 1: figs. 1a-c.

Crania turbinata (Poli)._Davidson, 1888:188, pl. 27: figs. 1423.

Description.-Three specimens only are referred to Crania anomala turbinata in the collections from the Gulf of Gascogne. Two of them (Thalassa 73: Z398, and Z413) are immature but the third from Biogas I, DS 01, which is figured here, is a young adult. This specimen is roundly elliptical, yellowish brown, and has a conical profile. Only the dorsal valve is available for examination. It is swollen and convex with the apex at 1.5 $\mathrm{mm}$ anterior to the posterior margin. The anterior and lateral slopes are steep, the posterior slope nearly vertical. The specimen is attached to a small pebble that also is host to a specimen of Macandrevia cranium (Müller) and a small barnacle.

The specimen from Thalassa Z413 is a very immature individual slightly less than $2 \mathrm{~mm}$ in 
diameter and with transparent shell. It is obviously in an early stage of development and represents only the apical part.

The other specimen, a dorsal valve, is also immature but larger than the preceding, and measures in $\mathrm{mm}$ : length 3 , width 3 , and about 0.8 thick. The shell is yellowish brown, squarish with rounded angles. The apex is slightly less than a third the valve length from the posterior margin. On the ventral side the fleshy parts are visible showing the adductor muscles.

Measurements (mm).-Length 6.5, width 7.5, height or thickness 3.5

TYPE.-Hypotype MNHN-BRA-78-44.

Discussion.-It has been difficult to decide what name to use for these specimens because the specific characters of the many names available for living Crania are as yet not firmly established. I therefore decided to use $C$. anomala turbinata (Poli), the name used by Fischer and Oehlert in their fine monograph on the collections made by the research vessels Talisman and Travailleur. The synonymy is skeletonized but will make it possible for an interested person to find available literature.

Davidson recognized the Mediterranean Crania as $C$. turbinata (Poli) but ignored the earlier name for the Mediterranean species Patella kermes Costa and Humphrey, which is the one Dall (1920) used for the Mediterranean form. Dall (1920) does not mention Poli's name, probably regarding it as non-binomial, a problem discussed by Fischer and Oehlert (1891:12). D'Hondt (1976:3) refers specimens from the Gulf of Gascogne to C. kermes Costa and Humphrey. A satisfactory study of the Mediterranean and Atlantic Cranias will require more extensive collections than those available at the National Museum of Natural History or the few found by Biogas and Thalassa.

Fischer and Oehlert (1891:10) record a specimen from the Gulf of Gascogne taken at 1068 meters. The specimens mentioned and figured herein ranged in depth from 310 to 1080 meters. The specimens identified by D'Hondt ranged in depth from 511 to 825 meters.

\section{Crania anomala (Müller)}

Plate 3: figures 12-14

Patella anomala Müller, 1776:237.-Davidson, 1888:183, pl. 27: figs. 1-9b.-Dall, 1920:269-271 [synonymy].

Description.- Three specimens are placed under this name. Two of them have flattish valves and round outline. The third specimen is immature. The apex of the two adults is low, about 4 $\mathrm{mm}$ high and located almost on the posterior margin. The posterior slope is short and steep. The anterior slope is broad and flatly concave. The color is pale brown.

These specimens are flatter and with the apex farther posterior than those referred to C. $a$. turbinata (Poli). The shape of Crania is often determined by the shape of its host and is not a dependable specific character. Larger collections than those available are needed for more accurate identification of these Cranias.

TYPE.-Hypotype: MNHN-BRA-78-60.

Stations.-Thalassa 70, W 368; Thalassa 71, X352.

\section{Genus Cryptopora Jeffreys, 1869}

\section{Cryptopora gnomon Jeffreys}

Plate 1: figures 22-25

Cryptopora gnomon Jeffreys, 1869:136.-Thomson, 1927:146, fig. 44.-Helmcke, 1939:253.-Muir-Wood, 1959:292.Cooper, 1959:22, pl. 5: fig. 16; 1973:11, pl. 8: figs. 14-16. Atretia gnomon Jeffreys, 1869:421.-Davidson, 1887:173, pl. 25: figs. 6-13.-Dall, 1920:293.

Neatretia gnomon (Jeffreys).-Fischer and Oehlert, 1891:123, fig. 11 .

Description.-This is a small smooth rhynchonellid having a length of about $3 \mathrm{~mm}$, rounded triangular in outline, narrowly lenticular in profile with the valves nearly equal in depth. The beak is pointed, the foramen large and triangular, and margined by narrow lateral (deltidial ?) plates. The shell when fresh is usually transparent but on death or decay becomes opaque white. The shell is impunctate but the calcite prisms 
composing it form a coarse mosaic that may be mistaken for punctae.

Inside the ventral valve there are prominent dental plates. Inside the dorsal valve a short but strongly elevated median septum with crest at midvalve is conspicuous and diagnostic. The crura are long, distally expanded to form an armand-hand like structure, a type of crus known as maniculifer (Cooper, 1959:9).

Cryptopora gnomon is generally an abyssal brachiopod as suggested by its transparent, thin, delicate shell. Its range is from 1190 meters to 4060 meters. In the Gulf of Gascogne its depth range is from 1913 to 2864 meters. The shallower water ranges off Florida given by Dall, (1920: 293) are for C. rectimarginata Cooper, a species with marked differences from $C$. gnomon.

Cryptopora gnomon is most commonly found in the North Atlantic off Greenland, Norway, Ireland, off the shores of New England and Maryland, off the Atlantic coast of Morocco, and in the Azores. Cooper (1973b:11) reports it from off the north coast of Panama in the Caribbean, its southernmost occurrence.

Measurements (mm).-Length 3.5, dorsal valve length 3.0 , width 2.8 , thickness 0.8 , apical angle $65^{\circ}$.

TYPE.-Hypotype: MNHN-BRA-78-41.

Stations.-Biogas V, KR 45; Biogas VI, DS 74, DS 87; Polygas DS 26; Thalassa 71, X334.

\section{Genus Hispanirhynchia Thomson, 1927}

\section{Hispanirhynchia cornea (Fischer)}

$$
\text { Plate 1: figures } 31-38
$$

Rhynchonella cornea (Fischer).-Davidson, 1887:171, pl. 25: figs. 2-4.

Rhynchonella (Hemithyris) cornea (Fischer). - Fischer and Oehlert, 1891:13, pl. 1: figs. 2a-u.

Hispanirhynchia cornea (Fischer).-Thomson, 1927:159, fig. 49._Helmcke, 1939:256._Cooper, 1959:59, pl. 10: figs. $1-21$.

Description.-This rhynchonellid is pale brown in color, triangular in outline, and very fincly capillate on the exterior. The shell sub- stance is impunctate, a fact by itself which distinguishes this species from other brachiopods from the Gulf of Gascogne except Cryptopora, which is also a rhynchonellid but is minute and its shell usually colorless.

Internally Hispanirhynchia cornea is readily separable from terebratulid brachiopods of the Gulf of Gascogne by its spiral lophophore which is coiled in a dorsal direction. This is a characteristic feature of all rhynchonellids.

Measurements (mm).-Length 23.7, dorsal valve length 21.5 , width 24.4 , thickness 13.8 , apical angle $72^{\circ}$ (specimen MNHN-BRA-7847a).

Types.-Hypotypes: MNHN-BRA-78-46a, $-47 \mathrm{a}$.

Stations.-Biogas II, DS 33, CV 21; Biogas III, CV 22; immature specimens from Thalassa 73, Z410, Z413, Z430, Z4435, Z447, and Z459.

Discussion.-Most of the specimens from the Gulf of Gascogne are attached to small pebbles by a short, slender pedicle. Unfortunately all of the specimens opened either in transit or when preserved, to spill their long slender lophophore outside the shell. Fischer and Oehlert (1891:15) measured its length at $6 \mathrm{cms}$ when fully extended.

Immature specimens were taken by Thalassa at several localities. These can be distinguished from Cryptopora by their rounder outline, less acute beak, poorly developed median septum, and pale yellow color. They can be distinguished from young Macandrevia, Fallax, and Dallina by the lack of punctae, which are usually very coarse in young terebratulids.

Fischer and Oehlert report the species from depths ranging from 822 meters off the Sudan to 2018 meters off Cape Finistere. In the Gulf of Gascogne the range is from 994 to 3645 meters. Fischer and Oehlert (1891:15) note its range as similar to that of Dallina septigera (Lovén) and Macandrevia cranium (Müller) but more restricted, and state that it often occurs with these two species. At Biogas II, CV 21 it occurs with the two species mentioned by Fischer and Oehlert but at the two other localities in the Gulf of 
Gascogne it occurs with Dallina septigera but $\mathrm{Ma}$ candrevia novangliae is substituted for $M$. cranium.

\section{Genus Terebratulina d'Orbigny, 1847}

\section{Terebratulina retusa emarginata (Risso)}

Plate 1: figures 13-21

Terebratula emarginata Risso, 1826:388, fig. 175.

Terebratula quadrata Risso, 1826:389, fig. 176.

Terebratula caputserpentis Philippi, 1836:94, pl. 6: figs. 5a, b.

Terebratula caputserpentis mediterranea Jeffreys, 1878:401.

Terebratulina caputserpentis Fischer and Oehlert [not Linné], 1891:37.

Terebratulina retusa emarginata (Risso)._Dall, 1920:296.

Distribution.-Terebratulina is perhaps the commonest living brachiopod. Except for the Antarctic, where it is rare, it is worldwide in distribution and is especially common in the North Atlantic, North Pacific, and Mediterranean, as well as off the east coast of North America and in the Caribbean. In the Atlantic two species are recognized, $T$. septentrionalis (Couthouy) and $T$. retusa (Linné). The former is generally found in the western Atlantic and the latter in the eastern Atlantic and Mediterranean. The few adult specimens from the Gulf of Gascogne available in this study are regarded as representing the subspecies emarginata of $T$. retusa that is best developed in the Mediterranean, although not confined there.

Description.-Adult T.r. emarginata from the Gulf of Gascogne is a medium-sized shell readily recognized by its almond shape and costellate exterior, large foramen, minute deltidial plates, and the loop of the dorsal valve in the form of a ring. The cardinalia are also different from other terebratulaceans discussed herein in not having the hinge plates in the form of a platform or forming a chamber. They are marginal at the posterior and thus affect the musculature. The dorsal pedicle muscles are attached to the valve floor rather than to outer hinge plates as in most other terebratulid genera.

The immature specimens from the Gulf of Gascogne, which have prominent beading on the costellae of the posterolateral flanks, yield some information on the development of the loop in the dorsal valve. The specimens are all in the collections of Thalassa, which include the young of several other genera. A specimen of $3 \mathrm{~mm}$ length of the dorsal valve shows descending branches only of the crura. A specimen with dorsal valve of $4 \mathrm{~mm}$ shows the crura lengthened and anteriorly bowed to face each other. A specimen with dorsal valve of $5.5 \mathrm{~mm}$ shows the anterolateral bands complete and uniting the two descending branches but the crural processes appear only as triangular points. In the adult the crural processes are joined to form a ring that is a generic character of most species of Terebratulina.

Measurements (mm).-Length 16.4, dorsal valve length 14.5 , width 12.5 , thickness 7.7 , apical angle $68^{\circ}$ (specimen MNHN-BRA-78-38a).

An interesting feature of Terebratulina is its pedicle, which may be long or short but is usually frayed at its distal extremity into numerous fibers that have the ability to penetrate limy objects to which the shell may attach itself. On less soluble pebbles they make a circle of fibers on the attachment surface.

The young of this subspecies, and of other terebratulinas as well, have a few strong costellae. The costellae on the posterolateral flanks are usually strongly beaded. This beading is lost or reduced in the adults (see Plate 1: figures 13-20).

The lophophore of Terebratulina (Plate 1: figure 21 ) is heavily spiculated so that on removal of fleshy tissue or drying, the lophophore maintains its original shape. So strong is the spiculation that some fossil terebratulinoids have been found with lophophore well preserved (Steinich, 1965:79; Rowell and Rundle, 1967).

Terebratulina retusa emarginata is recognized by having a median linear depression on the ventral valve and a flattening of the longtudinal median of the dorsal valve, thus producing a modest dorsad wave of the anterior commissure and a gentle emargination of the anterior margin.

TyPEs.-Hypotypes: MNHN-BRa-78-38a,b, $39 \mathrm{a}-\mathrm{d},-40,-43$.

Stations.-Biogas I, DS 01; Thalassa 70, 
W368; Thalassa 71, X312, X340, X348, X352, X360; Thalassa 73, Z392, Z397, Z398, Z399, Z402, Z424, Z427, Z436.

\section{Terebratulina retusa (Linné)}

Anomia retusa Linné, 1758: 701.-Dall 1920:294 [for synonymy].

Several immature specimens placed under this heading are too small for certain identification as the subspecies T.r. emarginata (Risso).

Stations.-Thalassa 70, W355; Thalassa 71, X340, X348, X352, X360; Thalassa 72, Y396.

\section{Genus Eucalathis Fischer and Oehlert, 1890}

\section{Eucalathis ergastica Fischer and Oehlert}

Plate 1: figures 1-8

Eucalathis ergastica Fischer and Oehlert, 1890a:73; 1891a:48, 132, pl. 3: figs. 6a-g.-Dall, 1920:324.

Description.-Small, suggesting an immature Terebratulina, subpentagonal to rounded triangular in outline; longer than wide, maximum width anterior to midvalve. Biconvex, subequivalve. Lateral commissure straight; anterior commissure rectimarginate. Beak short, straight, bearing a triangular foramen bounded by narrow interareas. Deltidial plates lacking. Surface marked by 24 costae that expand anteriorly, each costa tending to split anteriorly to produce short fascicles around the anterior and lateral margins. Color white to yellowish white.

Ventral valve moderately convex in anterior and lateral profiles. Median part somewhat flattened; lateral slopes moderately steep. Interior with strong, thick, teeth elongated parallel to shell margin and bounding narrow fossettes. Pedicle collar thick.

Dorsal valve swollen in the posterior half, with strongly convex umbonal region. Anteromedian portion flattened to form a sulcus. Interior with erect socket plates; short, stout crura leading to small but pointed crural processes. Loop anterior to crural processes forming a semicircle drawn slightly into a median point at its anterior. Crural processes never uniting as in Terebratulina.

Measurements ( $\mathrm{mm}$ ).-

\begin{tabular}{cccccc} 
& \multicolumn{3}{c}{$\begin{array}{c}\text { Dorsal } \\
\text { valve }\end{array}$} & Thick- Apical \\
Specimen & Length & length & Width & ness & angle \\
MNHN-BRA-78-35 & 4.7 & 3.9 & 4.4 & 2.3 & $90^{\circ}$ \\
MNHN-BRA-78-42 & 4.8 & 4.0 & 4.4 & $?$ & $90^{\circ}$
\end{tabular}

Discussion. - Eucalathis ergastica has been taken off the Atlantic coasts of Spain, Morocco, and Azores in addition to the Gulf of Gascogne. It occurs from 460 meters to 1226 meters in the waters cited above. In the Gulf of Gascogne the depths are 750-1080 meters. Although usually rare and inconspicuous, Eucalathis is widely distributed. It occurs in the Atlantic, Caribbean, Indian, south Pacific, and Antarctic oceans.

TyPes.-Hypotypes: MNHN-BRA-78-35, -36, $-42$.

Stations.-Thalassa 70, W369; Thalassa 73, Z393, Z409, Z435.

\section{Eucalathis tuberata (Jeffreys)}

Plate 1: figures 9-12

Terebratula tuberata Jeffreys, 1878:401, pl. 22: fig. 2.

Terebratulina tuberata (Jeffreys)._Davidson, 1870:400, pl. 19: figs. 20, 20a; 1880:13; 1886:39, 132, pl. 6: figs. 18-20.

Eucalathis tuberata (Jeffreys).-Fischer and Oehlert, 1891:43, pl. 2: figs. $5 \mathrm{a}-\mathrm{f}$.

Description.-Small, rounded triangular to subpentagonal in outline with greatest width anterior to middle. Inequivalve, ventral valve having greater depth. Lateral commissures straight; anterior commissure rectimarginate. Beak short, straight; foramen triangular; deltidial plates minute. Pedicle short or long, numerously frayed distally. Color yellowish white. Surface finely costellate, costellae numbering about $40-44$, with a median costa on the dorsal valve stronger than the others and a corresponding gap on the ventral side. Costellae strongly and minutely beaded.

Measurement (mm).-Length 3.1, dorsal valve length 2.5 , width 3.1 , thickness 1.5 , apical angle $90^{\circ}$ (specimen MNHN-BRA-78-37).

TyPes.-Hypotypes: MNHN-BRA-78-37, -61. 
Stations.-Thalassa 71, X340, X348, X353; Thalassa 73, Z394, Z410.

Discussion.-This species differs from $E$. ergastica Fischer and Oehlert in its shape and more numerous, beaded, radial costellae. This rare and little-known species is generally abyssal in its occurrence. Fischer and Oehlert (1891:45) record it from 896 to 2018 meters. Dall (1920:324) records it from 616 to 2995 meters. In the Gulf of Gascogne its depth range is 900 to 1080 meters. It has been found off the Atlantic coast of Morocco, the Azores, and in the Mediterranean.

\section{Genus Meonia Steinich, 1963}

\section{Meonia? species}

A remarkable brachiopod, taken by Thalassa 72 at locality Y407 at 740 meters, appears to be a form unknown in any Tertiary or Recent assemblage. The specimen evidently came from a fine gravel as indicated by a sample of the bottom in the specimen phial. The specimen appears to have relationship according to its exterior details to the Cretaceous genera Meonia Steinich (1963) and Orthothyris Cooper (1955), the former from the Maastrichtian of Denmark, the latter from the Cretaceous of Cuba.

The specimen is small, white, and measures nearly $3 \mathrm{~mm}$ in width and slightly more than 3 $\mathrm{mm}$ in length. It is concavo-convex with a hingeline nearly equal to the shell width. The ventral valve is strongly convex in anterior and lateral profiles. The dorsal valve is marked medianly by an anteriorly widening but shallow sulcus. Both valves are ornamented by about 20 subangular costae. The external appearance is similar to that of a small specimen of the Ordovician genus Orthambonites.

The two genera resembling that from Y407 also are orthoid in external appearance but both are known to belong to the Cancellothyridacea and are thus related to Terebratulina and Eucalathis. The loop of Meonia is known (Steinich 1963:733) and resembles that of Eucalathis. The loop of the Cuban genus Orthothyris is not known but the cardinalia are clearly those of the Cancellothyridacea (Cooper 1973a:389). The exterior of the specimen from Y407 is more like that of Orthothyris but that genus is not known from Europe. The exterior of European Meonia is sufficiently like that of the Y407 specimen to warrant tentative assignment to that genus. The specimen may be from submerged Cretaceous rocks or may have been transported from Cretaceous beds that crop out above sea-level to the east.

\section{Genus Gryphus Megerle von Mühlfeldt, 1811}

\section{Gryphus vitreus (Born)}

\author{
Plate 1: figures 27-30
}

Anomia vitrea Born, 1778:106._Gmelin, 1792:3347.

Terebratula vitrea (Born)._Lamarck, 1801:139; 1819:245._ Sowerby, 1846:353, pl. 70: figs. 56-59.-Philippi, 1836: 95, pl. 6: fig. 6._Costa, 1851-52:33, pl. 1: figs. 1-3.Reeve, 1860, pl. 3: fig. 8.- Davidson, 1870:8, pl. 117 : fig. 11.

Terebratula (Liothyris) vitrea (Born).-Deslongchamps, 1884: 106, pl. 20: figs. 7-11.

Liothyris vitrea (Born).-Douvillé, 1879:265, fig. 6.-Davidson, 1886:6, pl. 1: figs. 1-12.

Terebratula (Liothyrina) vitrea (Born).-Fischer and Oehlert, 1891:51, pl. 3: figs. 7a-h.

Liothyrina vitrea (Born).-Oehlert, 1887:1316, fig. 1104.

Gryphus vitreus (Born)._Megerle von Mühlfeldt, 1811:64.Dall, 1920:311._-Thomson, 1927:193, fig. 58.-Cox, 1934:226, figs. 1-4.-Hertlein and Grant, 1944:91.Muir-Wood, 1965:H780, figs. 643, 644a-d.

Description.-This is a large, white, widely oval, elongate terebratulid having subequally convex valves and usually a very small foramen in an incurved labiate beak. The shells are usually thin, translucent to transparent, but opaque in old or dead shells. The lateral commissure is straight and the anterior commissure rectimarginate. The partially visible symphytium is concave. Punctae number about 214 per square $\mathrm{mm}$.

The muscles of the interior of the shell have been described by Fischer and Oehlert (1891) and Cox (1934). The arrangement of these is similar to that of most other terebratulacean brachiopods that have their dorsal pedicle muscles attached to hinge plates. The cardinal process is 
a variable structure but is usually transversely elliptical, shelf-like, with roughened posterior face. In old shells its margins curl and a median ridge is formed producing two pits.

The loop is of considerable interest because it is unusual, not in its general aspect but in its details. The socket ridges are strong but thin plates, slightly inclined and distally expanded, bounding a narrow socket floored by a stout fulcral plate. The outer hinge plates are flat or gently concave, tapering anteriorly, and joining the very narrow crural base to form a narrow shaft (crus) that bears the scoop-shaped anterior half of the loop. The crural base is difficult to identify along the inner margin of the outer hinge plate. In some specimens it forms a slight ridge but in others it appears to be flush with the edge of the hinge plate. The crural processes are short, triangular, delicate, slightly approximate sharp points that arise abruptly from the distal end of the narrow crus slightly anterior to midloop. Anteriorly the crural processes descend to the anterior end of the loop where they form almost a right angle with the transverse band. The latter is broad, slightly arched, and with a low median crest. The anterior margin of the loop is gently convex in some specimens but in very well-preserved ones it is notched at the anterolateral extremities, giving the transverse band a tonguelike distal extremity. The posterior margin of the transverse band is more or less strongly concave toward the anterior. The loop is variable in respect to many of its features. It may be narrower in some specimens, wider in others. It is usually equal to about $1 / 3$ the dorsal valve length and varies from $20 \%$ to $25 \%$ of the valve width.

The mantle cavity is well filled by a plectolophous lophophore with large median coil and widely extended lateral lobes.

This species is variable in many of its parts. Its shape is often modified by the accidents of its position on the sea floor, whether crowded or free. Its pedicle foramen is variable in size, being minute in some forms-so minute in fact, that it is questionable if the pedicle was actually functional. The incurvature and labiation of the beak are variable. Deslongchamps (1884, pl. 20: figs. 7-11) describes an aberrant specimen with a large median septum in both valves.

Dall (1920:312) mentions two aberrations in the Jeffreys collection that were referred to by Jeffreys as $G$. v. elongatus and $G$. v. dilatatus. According to Dall there are 4 specimens of the former that are almost cylindrical, a fact that led Dall to state that the condition "can hardly be called a deformity." The other is subcircular and not so swollen as normal. Both aberrations are from off Sardinia.

Gryphus vitreus has a wide range of depths from 392 to 2661 meters according to Fischer and Oehlert (1891:53). Dall (1920:311) records it from depths of 73 to 1819 meters. Blochman (1908: 619) reports its depth range as 10-2700 meters. Specimens taken by Biogas and Thalassa from the Gulf of Gascogne are from 280-1980 meters. A shell fragment referred to this species from Biogas V, CP 07 was taken at 2170 meters.

Measurements (mm).-Length 35.2, dorsal valve length 31.4 , width 31.2 , thickness 18.0 , apical angle $83^{\circ}$ (specimen MNHN-BRA-7845a).

Gryphus vitreus is common in the Mediterranean and off the coasts of France, Portugal, and Spain.

TYPES.-Hypotypes: MNHN-BRA-78-45a,b.

Stations.-Biogas I, DS 01; Biogas V, CP 07; Thalassa 71, X341; Thalassa 73, Z398, Z399, Z402 (all immature).

\section{Gryphus? cooperi d'Hondt}

Plate 3: figures 1, 2

Gryphus cooperi d'Hondt, 1976:6, fig. 2.

Description.-One specimen of this species recently discovered in the Gulf of Gascogne was taken by Thalassa 71 , station X352, at 580-545 meters. The specimen is unfortunately damaged by crushing but the loop of the dorsal valve is well preserved. The specimen is $8 \mathrm{~mm}$ long by about $6 \mathrm{~mm}$ wide. The valves have been separated so that thickness cannot be measured. The exterior is marked by strong concentric undula- 
tions of growth over which are superimposed obscure radial lines. Both valves are moderately convex. The anterior commissure appears to have been rectimarginate. The interior of the ventral valve has a short pedicle collar, small oblique teeth, and no dental plates.

The loop and cardinalia of the dorsal valve are well preserved. The form of the loop is suggestive of that of Eucalathis. It has short crura that bear small crural processes located just anterior to the sockets. The outer hinge plates are small, triangular, flattish, and without a marginal elevation of the crural base. The descending lamellae are directed anteromedially and unite in a narrowly rounded medial point. The socket ridges are short, thin, and inclined laterally to bound short, narrow sockets.

Discussion.- The dimensions of this specimen do not conform with those of the types of G.? cooperi as it is more slender and elongate. It is also much smaller than the types illustrated by D'Hondt and may be rather a young form of $G$.? cooperi. However, the loop conforms well to that of the type specimens.

This species does not belong to the genus Gryphus because of the major differences in the loops of the two genera. The loop of $G$.? cooperi is more closely related to that of Dyscolia than to Gryphus. This is seen in the lack of crural bases along the inside margin of the outer hinge plate and in the nature of the transverse band. Dyscolia, which also occurs in the Gulf of Gascogne, has modified outer hinge plates like those of G.? cooperi and lacks marginal crural bases. D'Hondt (1976) gives the depth range of his species as 452-850 meters.

TYPE.-Hypotype: MNHN-BRA-78-11.

\section{Genus Dallithyris Muir-Wood, 1959}

\section{Dallithyris? aff. D.? sphenoidea (Jeffreys) not Philippi}

Plate 2: figures 36-38

Terebratula vitrea var. sphenoidea Jeffreys [not Philippi 1844], 1878:404, pl. 22: fig. 6 .
Liothyris sphenoidea (Jeffreys) [not Philippi].—Davidson, 1886: 12, pl. 2: figs. 17, 18 only.

Terebratula (Liothyrina) sphenoidea (Jeffreys) [not Philippi].Fischer and Oehlert, 1891:58, pl. 3: figs. 8a-m.

Liothyrina sphenoidea (Jeffreys) [not Philippi].-Blochmann, 1908:619, pl. 37: fig. 11; pl. 38: figs. 19a-c; pl. 39: figs. 23a,b.

Dallithyris sphenoidea (Jeffreys) [not Philippi].-Muir-Wood, 1959:304.

Description.-A single specimen of this species was taken by Biogas III (CV 22); it displays well the characters of this disputed brachiopod. The shell is white, thin, and translucent. It is elongate oval to pentagonal in outline; the sides are slightly rounded, diverging slightly to just beyond midvalve but then converging slightly toward the anterior margin, which is gently rounded. The ventral valve is much more convex than the dorsal one, which is shallow and gently convex in profile. The lateral commissure has a strong dorsal bend near midvalve; the anterior commissure is rectimarginate. The beak is short, suberect, moderately labiate, and truncated by a large, round, permesothyridid foramen. The pedicle valve is narrowly swollen from umbo to anterior margin, the swelling widening slightly anteriorly. The flanks of this valve are very steep.

Inside the dorsal valve the loop is very narrow, tapers anteriorly, and occupies about a third of the dorsal valve length. The outer hinge plates are concave, narrow, the crura short and narrow, attached to a spatuloid loop having obtusely angular crural processes and a very broad, narrowly arched, transverse band.

Measurements ( $\mathrm{mm}$ ).-Length 22.6, dorsal valve length 20.2 , width 16.3 , thickness 13.2 , apical angle $70^{\circ}$

TYPE.-Hypotype: MNHN-BRA-78-57.

Station.-Biogas III, CV 22.

Discussion.-This species, which appears to be confined to the eastern Atlantic, was originally identified by Jeffreys with the fossil form described by Philippi (1844:67, pl. 18: fig. 6) from Pliocene beds in Sicily. Comparison of the specimen from the Gulf of Gascogne with examples of the fossil from Sicily indicates that the two species are not the same. The fossil form is larger, with 
maximum width near midvalve, and has a much more convex dorsal valve. Dall (1920:316) and Muir-Wood (1959:304) regarded the Sicilian form and the modern one as distinct. The above synonymy is designed to indicate references to the modern form only. Although creation of a new species is in order, it cannot be done here because of insufficient material.

The generic assignment of this species is also difficult to establish at the present time. The loop and hinge plates are quite different from those of Gryphus. The valves have different proportions. Although the species in question externally resemble Dallithyris murrayi Muir-Wood (1959:302), there are important differences in the loops. Terebratula sphenoidea Jeffreys (not Philippi) is here assigned to Dallithyris with a query.

The modern species occurs outside the Gulf of Gascogne and Bay of Biscay off the Atlantic coasts of Spain, Morocco, and Portugal to the Azores and Canaries. It is found in the Mediterranean. It is commonly a deep-water species dwelling at depths of 400 to 2000 meters (Blochmann 1908:620). The specimen described herein was taken at 1331 meters.

\section{Genus Platidia Costa, 1852}

\section{Platidia anomioides (Scacchi and Philippi)}

$$
\text { Plate 2: figure } 18
$$

Orthis anomioides Scacchi and Philippi, 1844:69, pl. 18: fig. 9. Terebratula appressa Forbes, 1844:193.

Platidia anomioides (Scacchi and Philippi)._Costa, 1852:48, pl. 3; fig. 4, pl. 3bis: fig. 6.-Dall, 1870:14, figs. 20, 21.Davidson, 1880:55, pl. 4: figs. 10, 11.-Deslongchamps, 1884:160, pl. 13: fig. 19.-Fischer and Oehlert, 1891:92, pl. 8: figs. 14a-g.-Thomson, 1927:217, fig. 65.-Atkins, 1959a:103-132.-Cooper, 1973:21.

Platydia anomioides Davidson, 1887:152, pl. 21: figs. 15-19.

Description.-Eleven lots of this species were taken by Thalassa but only one of them contained an adult specimen. The genus is readily reocgnized by its nearly circular outline, the gently concave dorsal valve, and the nature of the pedicle region. The beak of the pedicle valve has a triangular pedical opening opposite a fairly wide, $V$-shaped aperture that takes up much of the umbonal region of the dorsal valve. These openings are covered by an integument that includes the short pedicle. Inside the valves there is a great development of the ventral pedicle muscles and a reduction of the diductors. The dorsal valve has a short loop consisting of descending branches united to an anteriorly elevated median septum.

The immature specimens range in size from slightly more than a millimeter to about three millimeters. The small specimens show no development of the septum and thus suggest the genus Amphithyris. The beginning of the median septum can be seen in an individual $2 \mathrm{~mm}$ wide (Thalassa 73, Z435).

Measurements (mm).-(Z435) length 3.5, dorsal valve length 3.0 , width 3.8 , thickness 1.0 .?

TyPE.-Hypotype: MNHN-BRA-78-49.

Stations.-Thalassa 71, X342, X347, X352; Thalassa 72, ?X395; Thalassa 73, Z399, X402, Z413, Z415, Z417, Z431, Z435.

The specimens from the Gulf of Gascogne were dredged by Thalassa from depths varying from 380 to 1050 meters. The species is known from many parts of the world: Mediterranean, Atlantic off Spain, Portugal, and Morocco, in the Caribbean, Gulf of Mexico, off South Africa, and off Marion Island in the South Pacific.

\section{Genus Megerlia King, 1850}

\section{Megerlia truncata (Linné)}

Plate 3: figures 5-11

Anomia truncala Linné, 1767:1152.

Megerlia truncata (Linné).-Davidson, 1887:103-108, pl. 19:

figs. 11-20.-Atkins 1961b:95-104.

Mühlfeldtia truncata (Linné).-Fischer and Oehlert, 1891:80-

87, pl. 7; figs. 11a-t.-Thomson, 1927:226.

M. disculus (Pallas).-Dall, 1920:333.

DESCRIPTION.-This is a common brachiopod in the Mediterranean, less so elsewhere. It is pale yellow or pale brown in color, wider than long, and subquadrate in outline. The valves are very variable and unequal in convexity, the dorsal valve being less convex than the ventral valve. The ventral valve is marked medially by a nar- 
row, rounded carination and the dorsal valve has a corresponding narrow sulcus. The surface is marked by fine radial lines.

Inside the dorsal valve is a long narrow loop with broad transverse band attached to the median septum. The adjustor muscles are greatly expanded in the ventral valve, the diductors are reduced in size and located posterior of the adductors.

In addition to the Mediterranean and Gulf of Gascogne, this species is known from the eastern Atlantic from Cape Breton to the Azores. It was found in the Gulf of Gascogne by Fischer and Oehlert at 411-550 meters. The specimen from Thalassa 70, W368 came from 137-400 meters. In the Mediterranean and Atlantic it usually occupies moderate deeps from 16-555 meters in the Mediterranean, and 64-550 meters in the Atlantic, according to Fischer and Oehlert (1891: 85). This species is known also from Pliocene rocks in the Mediterranean margins.

TYPES.-Hypotypes: MNHN-BRA-78-59a,b.

Station.-Thalassa 70, W368.

\section{Megerlia echinata (Fischer and Oehlert)}

$$
\text { Plate 3: figures 3, } 4
$$

Mühlfeldita echinala Fischer and Oehlert, 1890a:73; 1891:90, pl. 7: figs. 13a-g.-Cooper, 1977:125, pl. 17: figs. 14-22. Pantellaria echinala (Fischer and Oehlert)._Dall, 1920:336. Megerlia echinata (Fischer and Oehlert).--Atkins, 1961a: 8994.

Description. - This species is represented by a single young specimen. It differs from $M$. truncata (Linné) in having somewhat stronger radial markings and in having pronounced rows of short spines on the ventral valve. The ventral valve is less carinate than that of $M$. truncata. This species is usually not deformed and has a normal deltidial area in comparison to Pantellaria monstruosa (Scacchi). The interior of the dorsal valve of the Thalassa specimen reveals the initial pair of oblique plates near midvalve that are the beginning of the loop, which in adult form is the same as $M$. truncata. The specimen was taken at 1000 meters.

TYPE.-Hypotype: MNHN-BRA-78-58.

Station.-Thalassa 70, W355

\section{Genus Pantellaria Dall, 1919}

\section{Pantellaria monstruosa (Scacchi)}

Plate 3: figures $16-18$

Terebratula monstruosa Scacchi, 1838:17.-Costa, 1851-52:43, pl. 9: figs. 4,5 .

Megerlia truncata var. monstruosa (Scacchi).-Davidson, 1887: 108, pl. 19: figs 21, 22.

Mühlfedltia monstruosa (Scacchi)._.Fischer and Oehlert, 1891: 87, pl. 7: figs. $12 \mathrm{a}-\mathrm{c}$.

Pantellaria monstruosa (Scacchi).-Dall, 1920:335.-Thomson, 1927:228.

Description.-This species is characterized by irregularity and distortion because it lives closely appressed to the substrate. This close appression causes abrasion of the dorsal umbo and dorsal ornament. The result is that the foramen is enlarged to include the umbonal region of the dorsal valve, a condition like that of Platidia. Because of its close appression the dorsal valve is smooth but the ventral valve has fine radial sculpture like that of Megerlia. The loop of the dorsal valve is exactly the same as that of Megerlia but may be distorted because of close attachment to the substrate.

In the Mediterranean, the species is often associated with $M$. truncata (Linné) leading to the suspicion that it might not be a good species. However, Fischer and Oehlert found it in isolated situations as seems the case with the specimen taken by Thalassa 71 (W352). In the Mediterranean, its depth range is $36-553$ meters. In the Gulf of Gascogne its range is 411 (Fischer and Oehlert) to 580 meters (Thalassa 71). The Travailleur dredged $P$. monstruosa at depths from 411 1068 meters. The species has been taken as a fossil from the Pleistocene of Sicily (Fischer and Oehlert, 1891:89).

TYPE.-Hypotype: MNHN-BRA-78-62.

Station.-Thalassa 71, X352.

Genus Macandrevia King, 1859

\section{Macandrevia cranium (Müller)}

Figures 2, 3; Plate 2: figures 19-30

Terebratula cranium Müller, 1776:249._Sowerby, 1847:354, pl. 70: figs. 60-62._Davidson, 1855:10, fig. 8. 
Waldheimia cranium (Müller).-Gray, 1853:58.-Hancock, 1858, pl. 53: figs. $3,4,9$; pl. 54: figs 2-7.-Dall, 1870 : 110.-Friele, 1877:380, pl. 1-3: figs. 1-4, 7a, 8-11.-Sars, 1878:10, pl. 1: figs. 3a-c.

Waldheimia (Macandrevia) cranium (Müller).-Davidson, 1887: 61, pl. 12: figs. 11-23; pl. 13: figs. 1, 2.

Magellania (Macandrevia) cranium (Müller).-Fischer and Oehlert, 1891:72-79, pl. 5: figs. 10a-s.

Terebratula glabra Leach 1852:359, pl. 13: figs. 3-5.

Macandrevia cranium (Müller)._King, 1859:261._Dall, 1877: 45._Helmcke, 1939:243._Elliott, 1958:3-6.-Atkins, 1959b:335-350.-Cooper, 1973b:24.

Distribution.-Macandrevia cranium (Müller) is one of the commoner and better known brachiopods. It is widely distributed and occurs along the shores of well populated northern countries so that it has been frequently collected. Its anatomy was described and beautifully illustrated by Hancock (1858). The species is widely distributed in the North Atlantic where it is found off Norway, Scotland, Greenland, Iceland, Ireland, Spain, Sicily, and France. It was taken from off Nova Scotia by the R/V Vema (Cooper, 1973b:24). It enjoys a considerable bathymetric range from one fathom (1.83 meters) to 1000 meters. It is the only species of Macandrevia inhabiting relatively shallow water except for one report of $M$. americana Dall in 122 fathoms off the coast of Chile.

DEscription.-Four lots of adults of this species taken by Biogas display some variation, the lot from Biogas 1, DS 01 consists of 44 specimens ranging in size from $12 \mathrm{~mm}$ to almost $24 \mathrm{~mm}$. The specimens (Plate 2: figures 19-24) are cream colored, elongate oval in outline with a tendency for the anterior margin to be truncated. The shells range in thickness from $6 \mathrm{~mm}$ to $13 \mathrm{~mm}$. The $\mathrm{L} / \mathrm{W}$ index is 1.22 and that of the $\mathrm{T} / \mathrm{W}$ is 0.66 . Inside the dorsal valve the loop varies in width with the width of the shell but its length is usually between $70 \%$ and $80 \%$ of the dorsal valve length and its width. These figures are in strong contrast to those of the smaller Macandrevia novangliae Dall, reported herein from the Gulf of Gascogne for the first time.

Adult Macandrevia cranium is identified in three other localities: the Biogas I, CM 01, CW 01, and Biogas II, CV 21. In each of these localities the specimens are somewhat larger than those described above and are a pale brown color, rather than cream color. Their dimensions are in accordance with those of Biogas I, DS 01, and their outlines, which are variable, are in accordance with the variations of outline and thickness exhibited by the first (DS 01) lot.

The depth range of these four lots is from 280 meters to 994 meters, a wide diversity of depths. Although all of the specimens from DS 01 clearly belong to $M$. cranium, all are slightly smaller than the length attained by this species in more nothern waters where a robust form from Norway will measure slightly more than $25 \mathrm{~mm}$ in length. A single dorsal valve from off the Shetlands measures $26 \mathrm{~mm}$ in length, indicating a complete specimen of at least $28 \mathrm{~mm}$ long.

TyPes.-Hypotypes: MNHN-BRA-78-50a-d, $-51,-52$.

Stations.-Biogas I, DS 01, CM 01, CW 01; Biogas II, CV 21, Thalassa 73, Z409. Specimens reported as Macandrevia species are all young forms, probably belonging here because of the relatively shallower depth at which they were dredged: Thalassa 73, Z394, Z397, Z407, Z410, Z413, Z416, Z417, Z421, Z427, Z430, Z431, Z436, Z437, Z459; Thalassa 71, X304, X340;

D'Hondt records this species from the Gulf of Gascogne at a depth of 2070 meters. This is deeper than the record of any specimen of $M$. cranium found by Fischer and Oehlert or by Dall (1920:354, 355) and by Biogas and Thalassa from the Gulf of Gascogne. Macandrevia novangliae commonly occurs in deeper water than $M$. cranium and could be confused with that better known species.

\section{Macandrevia novangliae Dall}

Figures 4, 5; Plate 2: figures 1-17

Macandrevia cranium, new var. novangliae Dall, 1920:355. Macandrevia novanglıae Cooper, 1977:127, pl. 26: figs. 1-11.

Description.-Small for genus, widely oval in outline, longer than wide with length equal to or up to $35 \%$ more than width. Biconvex with thick- 


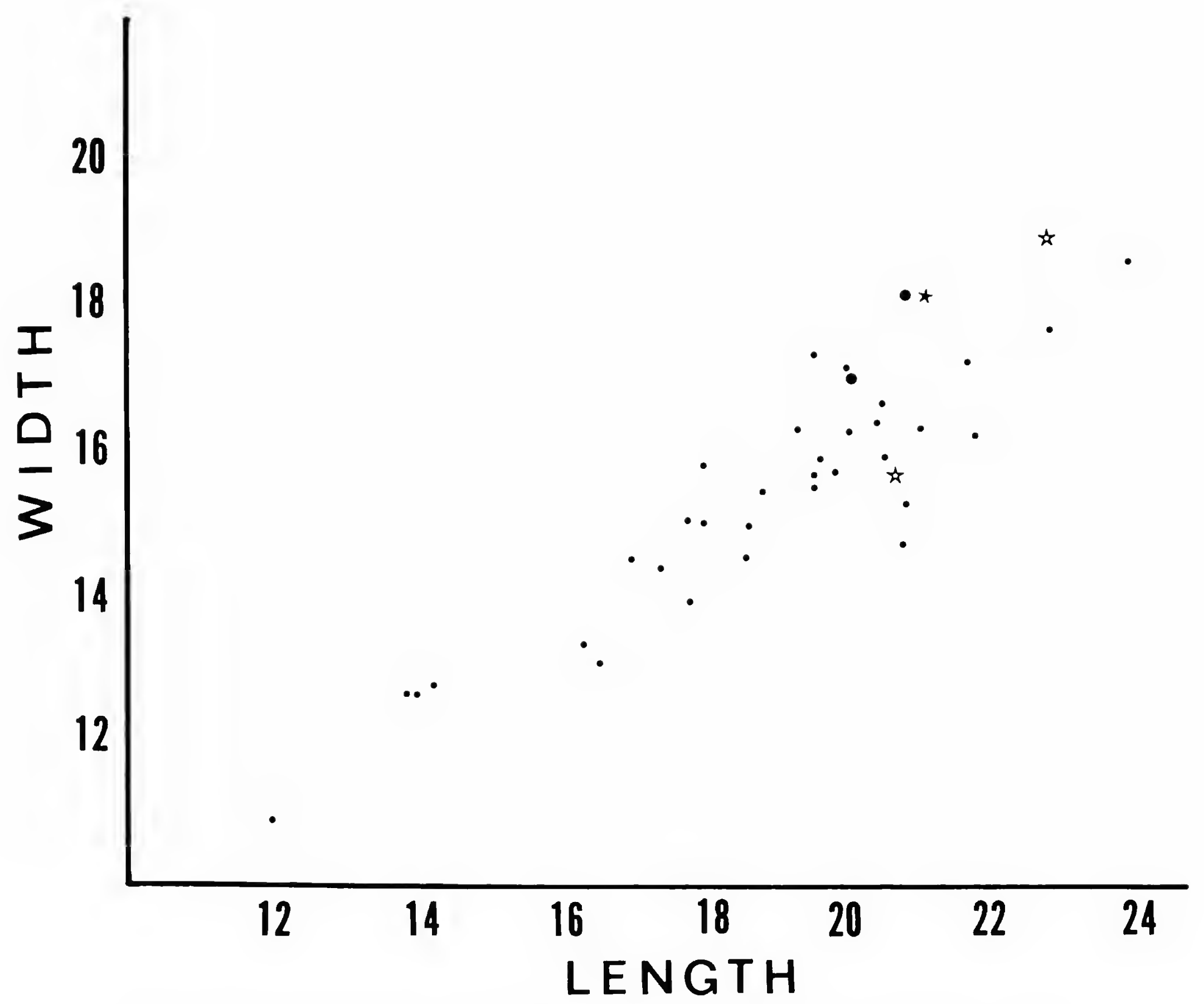

Figure 2.-Scattergram showing relationship of length and width of Macandrevia cranium (Müller) (small dot = Biogas I, DS 01; dark star = Biogas I, CW 01; large dot = Biogas I, CM 01; open star = Biogas II, CV 21).

ness equal to about $66 \%$ of width. Sides rounded; anterior margin gently rounded to flattened; posterolateral margins forming angle of $70^{\circ}-100^{\circ}$ Lateral commissure straight; anterior commissure rectimarginate with tendency to faint sulcation in some specimens. Beak short, truncated, erect; beak ridges prominent and marking narrow interarea; foramen round, anteriorly truncated; no deltidial plates. Pedicle long and slender or short and frayed distally so that it barely protrudes from the foramen. Shell white when weathered or worn, usually covered by a thin, light brown periostracum. Surface marked by incremental lines of growth only. Punctae about $170 / \mathrm{mm}^{2}$.

Ventral valve evenly and moderately convex in lateral profile, curvature increasing slightly in umbonal region. Anterior profile somewhat narrowly swollen, with steep sides. Umbonal region swollen; anterior slope moderately steep.

Dorsal valve less convex than ventral one; gently convex in lateral profile, anterior abrupt and steep. Anterior profile gently convex with sides abrupt, steep. Umbonal region moderately swollen. 


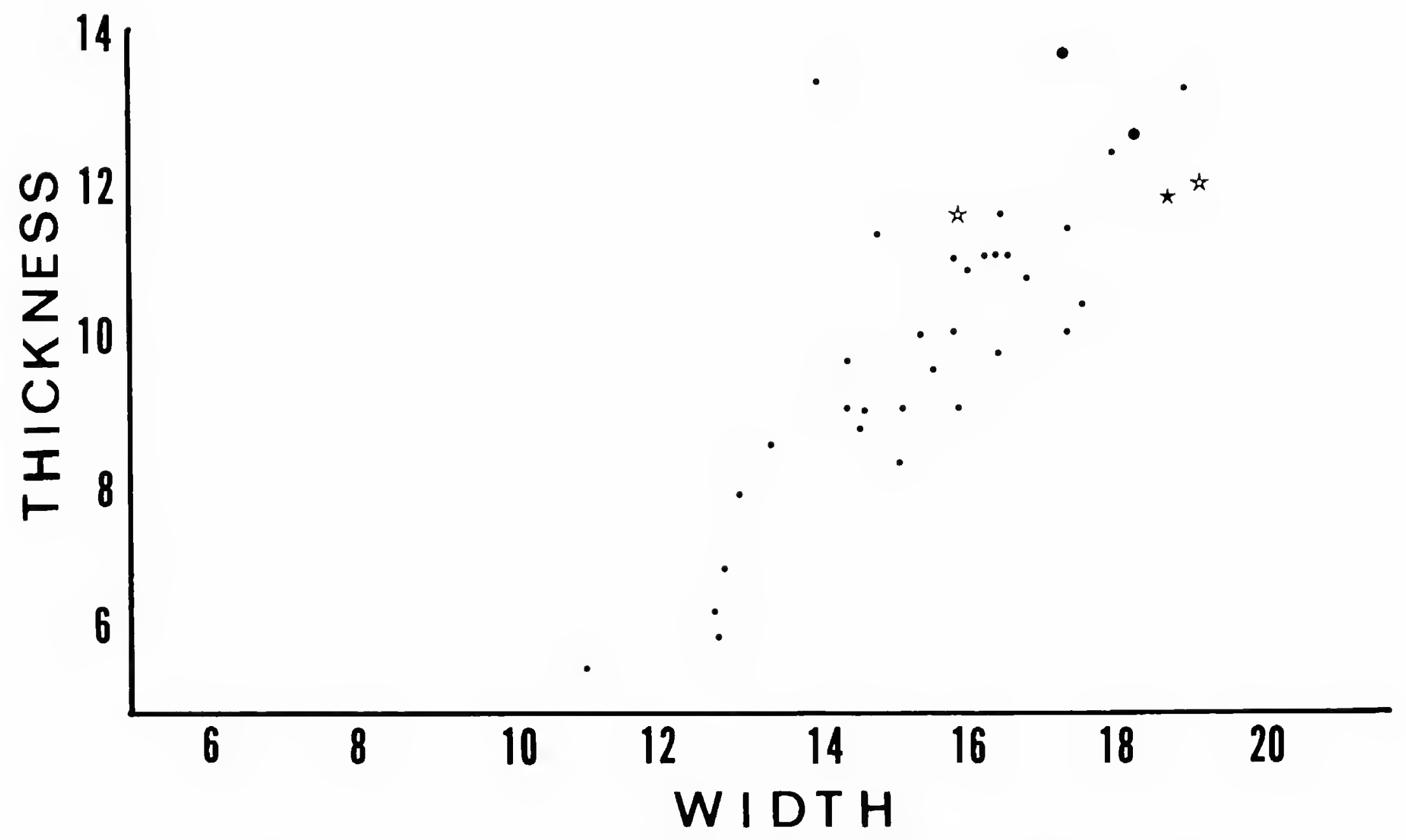

FIGURE 3.-Scattergram showing relationship of thickness to width of Macandrevia cranium (Müller) (small dot = Biogas I, DS 01; dark star = Biogas I, CW 01; large dot = Biogas I, CM 01; open star = Biogas II, CV 21).

Ventral valve with small cyrtomatodont teeth buttressed by strong, short dental plates. Delthyrial cavity strongly thickened. No pedicle collar. Muscle field lightly impressed; vascula media well developed posteriorly.

Dorsal valve with short, stout, slightly inclined socket ridges and thick fulcral plates. Outer hinge plates narrow, flattened, tapering into short and narrow crus. Inner hinge plates thin, inclined inward, and meeting floor to bound a narrow notothyrial cavity; inner hinge plates tapering anteriorly and extending for about $1 / 3$ valve length. Diductor muscle attachments in pit at apex, not forming boss. Delthyrial cavity marked medially by low ridge or myophragm separating elongate attachments of dorsal pedical muscles. Loop long; crural processes small, sharply pointed, located about $1 / 4$ length of loop anterior to apex; descending lamellae of loop narrow ribbons inclined slightly medially; ascending la- mellae broad, widening posteriorly where they join broad, flattened, transverse band with apical median reentrant bounded by blunt points.

\begin{tabular}{|c|c|c|c|c|c|}
\hline Specimen & Length & $\begin{array}{l}\text { Dorsal } \\
\text { value } \\
\text { length }\end{array}$ & Width & $\begin{array}{c}\text { Thick- } \\
\text { ness }\end{array}$ & $\begin{array}{c}\text { Apical } \\
\text { angle }\end{array}$ \\
\hline NHN-BRA-78-48a & 13.2 & 11.5 & 10.9 & 7.8 & $100^{\circ}$ \\
\hline HN-BRA-78-48b & 14.3 & 12.8 & 12.6 & 7.9 & $95^{\circ}$ \\
\hline IN-BRA-78-48c & 14.2 & 12.3 & 10.4 & 8.3 & $62^{\circ}$ \\
\hline HN-BRA-78-48d & 14.6 & 13.2 & 11.9 & 8.2 & $95^{\circ}$ \\
\hline IN-BRA-78-48e & 13.3 & 11.6 & 11.2 & 7.5 & $84^{\circ}$ \\
\hline IN-BRA-78-48 & 13.8 & 11.9 & 11.2 & 8.5 & $78^{\circ}$ \\
\hline IN-BRA-78-48 & 16.5 & 14.6 & 12.4 & 9.3 & $71^{\circ}$ \\
\hline
\end{tabular}

Diagnosis. - Small, roundly pentagonal Macandrevia with length approximately $20 \%$ greater than the width.

Types.-Holotype: USNM 78069; paratypes: USNM, 49068, 50668, 78340. Figured hypotypes: MNHN-BRA-78-48a,b,d,f,h. 


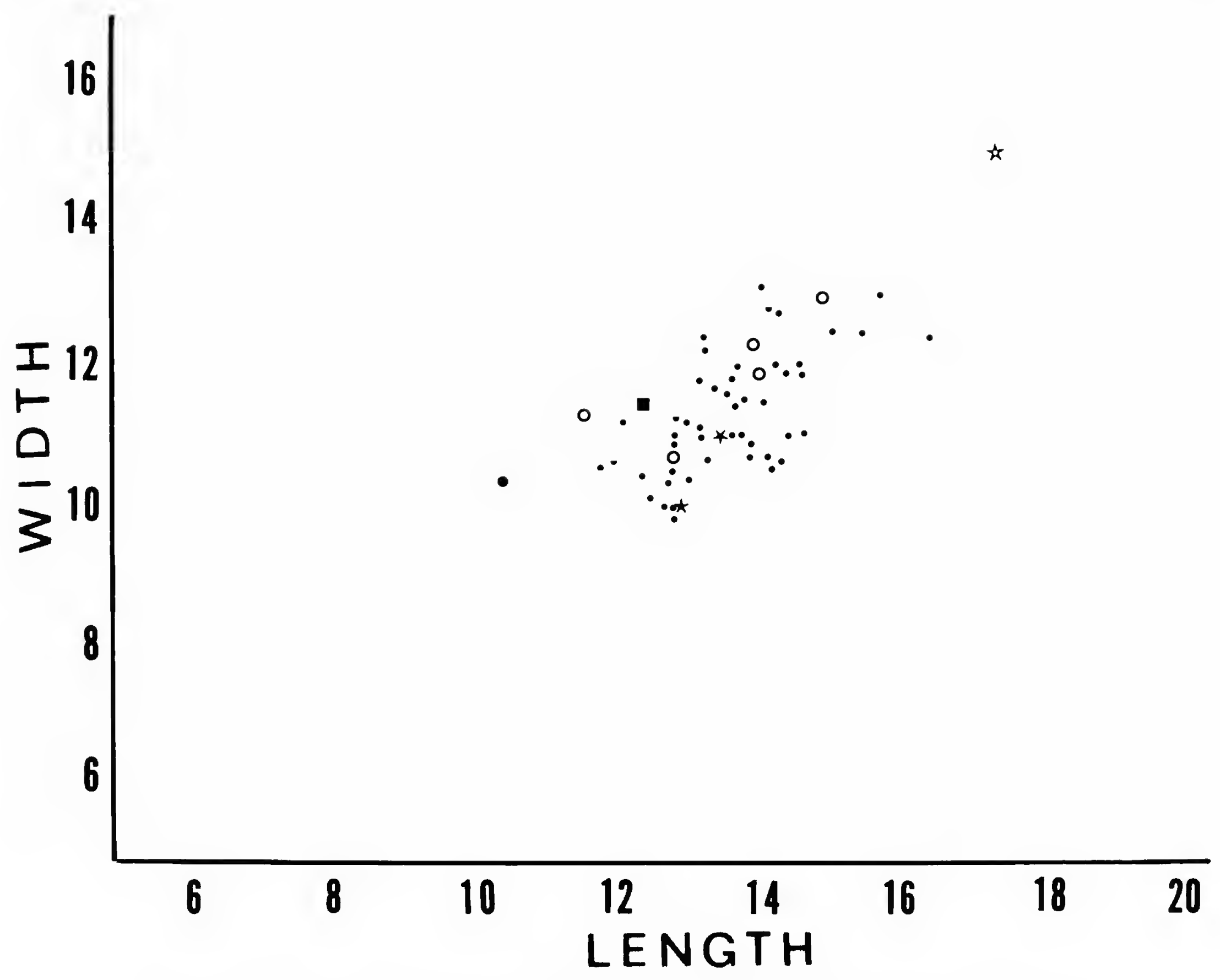

FIGURE 4.-Scattergram showing relationship of length and width of Macandrevia novangliae Dall (small dot = Biogas V, CP 07; open circle = specimen from off New Jersey, U.S.A.; dark star = Biogas VI, CP 23; large dot = Biogas IV, CP 03; open star = Biogas II, DS 33; dark square = Biogas VI, CP 09).

Stations.-Biogas II, DS 33?; Biogas III, CV 22?, CV 23, CV 24, CV 32; Biogas IV, CP 03; Biogas V, CP 07; Biogas VI, CP 09, CP 23; Polygas CV 10, CV 11.

Comparison.-This species need be compared only to the smaller members of the genus: Macandrevia craniella Dall, $M$. tenera Jeffreys, and the fossil M. euthyra (Philippi). Macandrevia craniella is a larger and relatively narrower species than $M$. novangliae. From $M$. tenera, which is similar in size, it differs in being a more compact form and more strongly pentagonal. It is wider than $M$. tenera, which is somewhat elongate. The loop of $M$. tenera is about $70 \%$ of the dorsal valve length and it is about $31 \%$ of the dorsal valve width. The loop of $M$. tenera has width/length relationship of 0.36 . These dimensions of the loop of $M$. tenera are quite different from those of $M$. novangliae. The width/ length relationship of the loop of $M$. novangliae is 0.65 and it occupies about half the length and $36 \%$ of the width of the dorsal valve.

Macandrevia novangliae is similar in shape to $M$. euthrya from the Pliocene of the Mediterranean but the fossil form is much larger. 


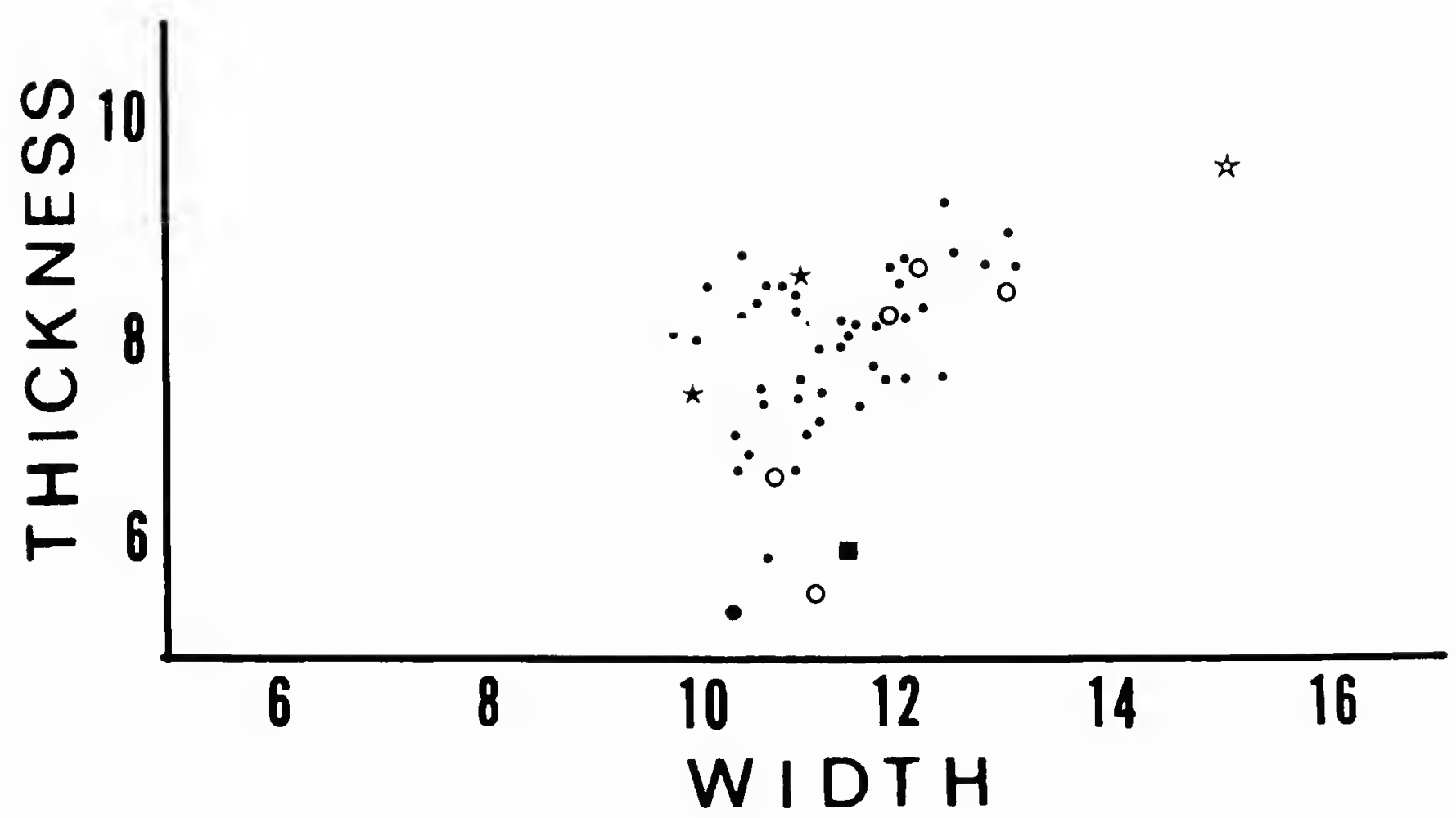

Figure 5.-Scattergram showing relationship of thickness and width of Macandrevia novangliae Dall (small dot = Biogas V, CP 07; open circle = specimen from off New Jersey, U.S.A.; dark star = Biogas VI, CP 23; large dot = Biogas IV, CP 03; open star = Biogas II, DS 33; dark square = Biogas VI, CP 09).

Macandrevia novangliae externally resembles Dallina parva, new species, in size and color but the two are readily distinguished by lack of deltidial plates and dorsal median septum and presence of dental plates; in Dallina parva dental plates are lacking and a median septum and deltidial plates are present.

A specimen from Biogas II, DS 33 and one from Biogas III, CV 22 are wider and larger than usual for $M$. novangliae. They are placed here with a query as they occur in fairly deep water.

Discussion.-Macandrevia novangliae is not a well known species as it occurs in very deep water off the New England coast of the United States ranging in depth from 1837 to 2174 meters. The report that the type specimen was taken at 137 meters (Dall 1920:355) is an error; the specimen actually comes from 1837 meters. The bathymetric range of the specimens from Gulf of Gascogne is similar to that of the New England ones, the range being 1895 to 2338 meters. Macandrevia novangliae inhabits much deeper water than $M$. cranium (Müller). The record by d'Hondt (1976: 2) of $M$. cranium from 2070 meters suggests $M$. novangliae rather than $M$. cranium.

\section{Genus Fallax Atkins, 1960}

Fallax Atkins, 1960a:72.

Description.-This genus is a homeomorph of Dallina but differs in its adult condition from that genus in the possession of dental plates in the ventral valve and in having its adult loop in the campagiform stage, that is, the descending lamellae of the loop are still attached to the median septum. The genus was first seen in the western approaches of the English Channel, where it was dredged in waters at depths ranging from 915 to 1190 meters.

\section{Fallax dalliniformis Atkins}

Plate 2: figures 31-35

Dallina septigera Fischer and Oehlert [not Lovén], 1891, pl. 4: figs $9 \mathrm{aa}, \mathrm{ab}, 9 \mathrm{r}-\mathrm{u}$; pl 5: figs $9 \mathrm{a}-\mathrm{c} \mid=$ Fallax dalliniformis Atkins].

Fallax dalliniformis Atkins, 1960a:71-89, pl. 1: figs. 1-5.

Description.-About medium size, pentagonal in outline, wider than long; inequivalve, ventral valve having greater depth. Sides nearly 
straight, forming shoulders with posterolateral margins. Beak forming angle of $80^{\circ}$, small, short, erect, and truncated by small, round, mesothyridid foramen, breached on its ventral side. Symphytium visible. Lateral commissure strongly curved toward dorsal valve; anterior commissure broadly sulcate but incipiently intraplicate. Color white, with traces of thin, light brown periostracum.

Ventral valve strongly convex in lateral profile with maximum curvature in umbonal region. Anterior profile forming steep-sided arch. Anteromedian region flattened and slightly depressed to form broad, shallow sulcus. Flanks nearly vertical.

Dorsal valve strongly convex in lateral profile, with abrupt ventrad curvature near front. Anterior profile broadly and very gently convex, with only slight development of narrow flanks. Median third swollen into gentle fold that opposes faint sulcus of ventral valve.

INTERIOR. - Ventral valve with short dental plates and loop attached to median septum.

Measurements (mm).-Length 20.6; dorsal valve length 17.0; midwidth 15.5; maximum width at anterior 16.2; thickness 13.2; apical angle $80^{\circ}$

TyPe.-Hypotype: MNHN-BRA-78-53.

Station.-Biogas III, CV 22.

Comparison.-Fallax is an external homeomorph of Dallina septigera (Lovén) with which it has been found. It is a narrower shell with more nearly straight sides when compared to Dallina. The more striking differences are on the interior of both valves. The ventral valve of Fallax has dental plates but these are not present in adult Dallina septigera. The major difference is in the loop of the dorsal valve, that of Dallina is completely free of the median septum with all attachments resorbed, whereas the loop of Fallax has the descending lamellae tied to the median septum by lateral branches. Actually the loop of Dallina passes through a fallax-stage (campagiform) in its development. In Fallax on the other hand adulthood is reached before freeing the loop and the arrested stage is typical of the genus.

Discussion.-Fallax occurs in the Pliocene of
Sicily. Fallax is probably more widespread than now recognized in both fossil and Recent occurrences. Foster (1974:88) records a modern species from the Antarctic.

\section{Genus Dallina Beecher, 1893}

\section{Dallina septigera (Lovén)}

Plate 2: figures 41-43

Terebratula septigera Lovén, 1846:29.

Waldheimia septigera (Lovén).-Gray, 1852:59.-Davidson, 1855:441, pl. 10: fig. 1.-Dall, 1871:13, pl. 1: fig. 4; pl. 2: fig. 9.-Friele, 1877:380, pl. 3: figs. 5, 6; pl. 4: figs. 12 14.-Davidson, 1886:56, pl. 11: figs. 1-10.

Dallina septigera (Lovén)._Dall, 1920:357.-Helmcke, 1939: 247, fig. 258.-Atkins, 1960b:91-99, pl. 1.

Description.-This species is homeomorphous with Fallax dalliniformis Atkins but usually can be distinguished by its more triangular shell, with the greatest width at the anterior. The interior details, however, are the final recourse in determining the generic character. Adult $D$. septigera is without dental plates and the loop is unsupported except by crura. The species occurs fairly commonly in the northeastern and eastern Atlantic, off Norway, Scotland, Ireland, Spain, Portugal, and Morocco. It ranges in depth from 108 to 2338 meters. The latter depth recorded from two specimens from Biogas II DS, 33 is the deepest record for the species.

Except for the fact that $D$. septigera and Fallax dalliniformis are often confused, the anatomy of the former is very well known. After her discovery of Fallax, Atkins (1960b) redescribed Dallina in considerable detail.

Measurements ( $\mathrm{mm}$ ).-Length 28.8, dorsal valve length 25.0 , width 25.2 , thickness 18.4 , apical angle $70^{\circ}$, (Biogas I, CM 01).

TyPE.-Hypotype: MNHN-BRA-78-56.

Stations.-Biogas I, CM 01; Biogas II, DS 33, CV 21; Biogas IV, DS 52, DS 62: Thalassa 71, X341, Thalassa 73, Z410, Z414, Z417, Z421, Z425, Z435. All but Z410 and the last of the Thalassa localities yielded only immature specimens impossible to identify generically, whether Fallax or Dallina, because the immature forms of 
the two are nearly identical. For convenience these tiny specimens are recorded as $D$. septigera because it is the more common species of Dallina.

\section{Dallina parva, new species}

Plate 3: figures 19-36

Description.--Small, wider than long, subtriangular in outline with maximum width at bounded by steep inner hinge plates. Loop long, occupying about $2 / 3$ valve interior, with delicate and slender descending lamellae supporting an expanded and ascending element and transverse band. Loop in young attached to crest of median septum but free in adult. Loop freed from septum after dorsal valve attains seven millimeters of length.

$$
\text { Measurements (mm) - - }
$$

$\begin{array}{lcccccc}\text { Specimen } & \text { Length } & \begin{array}{c}\text { Dorsal } \\ \text { valve } \\ \text { length }\end{array} & \begin{array}{c}\text { Mid- } \\ \text { width }\end{array} & \begin{array}{c}\text { Maximum } \\ \text { width }\end{array} & \begin{array}{c}\text { Thick- } \\ \text { ness }\end{array} & \begin{array}{c}\text { Apical } \\ \text { angle }\end{array} \\ \text { MNHN-BRA-78-63a } & 11.0 & 9.7 & 8.3 & 8.8 & 6.5 & 72^{\circ} \\ \text { MNHN-BRA-78-63b } & 10.2 & 9.0 & 7.1 & 8.5 & 6.5 & 72^{\circ} \\ \text { MNHN-BRA78-63c } & 8.3 & 7.1 & 6.4 & 6.9 & 4.6 & 74^{\circ}\end{array}$

anterior; sides gently rounded and forming angle of about $70^{\circ}$. Anterolateral extremities somewhat narrowly rounded; anterior margin gently rounded. Lateral commissure slightly concave toward ventral side; anterior commissure broadly and gently sulcate. Beak narrow, suberect; foramen small, round, mesothyridid; symphytium concave, almost wholly visible. Surface marked by concentric lines of growth only, often crowded anteriorly. Color yellow to pale brown.

Ventral valve interior without pedicle collar; hinge teeth small; no dental plates seen in young or adult specimens. Diductor scars large widely separated, deeply incised.

Dorsal valve interior with median septum long, reaching for three fourths valve length, rising to sharply pointed crest at $1 / 4$ valve length, then tapering to disappearance anteriorly. Notothyrial chamber small, about $1 / 5$ to $1 / 6$ valve length,
TyPes.-Holotype: MNHN-BRA-78-63b; figured paratypes: MNHN-BRA-78-63a, d-i; unfigured paratype: MNHN-BRA-78-63c.

Station.-Thalassa 71, X340.

Diagnosis.-The smallest known Dallina characterized by gentle sulcation of the anterior commissure and lack of dental plates in the young.

Discussion.-The small size of these specimens made their assignment to Dallina suspect, but the absence of dental plates and the free loop in the adult makes identification with Dallina correct.

\section{Dallina species}

Under this name are recorded specimens of immature Dallina that cannot be placed specifically.

Thalassa 71, X312, X342, X343, X345, X347, X348, X352, X353; Thalassa 72, Y395, Y401. 


\section{Literature Cited}

Atkins, D.

1959a. The Growth Stages of the Lophophore of the Brachiopods Platidia davidsoni (Eudes Deslongchamps) and Platidia anomioides (Philippi), with Notes on the Feeding Mechanism. Journal of the Marine Biological Association of the United Kingdom, 38:103-132.

1959b. The Early Growth Stages and Adult Structure of the Lophophore of Macandrevia cranium (Müller) (Brachiopoda, Dallinidae). Journal of the Marine Biological Association of the United Kingdom, 38:335350.

1960a. A New Species and Genus of Brachiopoda from the Western Approaches, and the Growth Stages of the Lophophore. Journal of the Marine Biological Association of the United Kingdom, 39:71-89.

1960b. A Note on Dallina septigera (Lovén) (Brachiopoda, Dallinidae). Journal of the Marine Biological Association of the United Kingdom, 39:91-99, plate 1.

1961a. The Generic Position of the Brachiopod Megerlia echinata (Fischer and Oehlert). Journal of the Marine Biological Association of the United Kingdom, 41:8994.

1961b. The Growth Stages and Adult Structure of the Brachiopods Megerlia truncata (L.) and M. echinata (Fischer and Oehlert). Journal of the Marine Biological Association of the United Kingdom, 41:95-111, 16 figures.

Beecher, C. E.

1893. Revision of the Families of Loop-bearing Brachiopoda. Transactions of the Connecticut Academy of Arts and Sciences, 9:376-399, 3 plates.

Blochmann, F.

1908. Zur Systematik und geographischen Verbreitung der Brachiopoden. Zeitschrift für wissenschafliche Zoologie, Leipzig, 90:596-644, plates 36-40.

Born, I. E.

1778. Index rerum naturalium Musei Caesarei Vindobonensis, 1: Testacea. Verzeichnis der natürlichen Seltenheiten des K. K. Naturalien Cabinets zu Wien, 1, Schaltiere. 458 pages, 1 plate. Vienna.

Cooper, G. A.

1955. New Brachiopods from Cuba. Journal of Paleontology, 29(1):64-70, plate 15.

1959. Genera of Tertiary and Recent Rhynchonelloid Brachiopods. Smithsonian Miscellaneous Collections, 139(5): 90 pages, 22 plates. 1973a. Fossil and Recent Cancellothyridacea (Brachiopoda). Science Reports of the Tohoku University (Sendai, Japan), series 2 (Geology), 6 (Hatai Memorial Volume):371-390, pls. 42-46.

1973b. Vema's Brachiopoda (Recent). Smithsonian Contributions to Paleobiology, 17: 51 pages, 9 plates.

1977. Brachiopods from the Caribbean Sea and Adjacent Waters. Studies in Tropical Oceanography, 14: 211 pages, 35 plates. Coral Gables, Florida: University of Miami Press.

Costa, O. G.

1851-52. Brachiopods. In Fauna del Regno di Napoli ossia enumerazione di tutti gli Animale-contenente la descrizione de nuovi o poco esaltamente conosciuti-di Costa (continuata da A. Costa), part 5: 60 pages, 9 plates, Naples.

Cox, I.

1934. Notes on the Shell Musculature of Gryphus vitreus (Born). Geological Magazine, 71 (839):226-230.

Dall, W. H.

1870. A Revision of the Terebratulidae and Lingulidae with Remarks on and Description of Some Recent Forms. American Journal of Conchology, 6(2):88-168, figures 1-38, plates 6-8.

1871. Report on the Brachiopoda of the Straits of Florida, in Charge of L. F. de Pourtales, with a Revision of the Craniidae and Discinidae Obtained by the U. S. Coast Survey Expedition. Bulletin of the Museum of Comparative Zoology at Harvard University, 3(1): 45 pages, 2 plates.

1873. Catalogue of the Recent Species of the Class Brachiopoda. In Proceedings of the Academy of Natural Sciences of Philadelphia for 1873:177-204.

1877. Index to the Names Which Have Been Applied to the Subdivision of the Class Brachiopoda, Excluding the Rudistes, Previous to the Year 1877. Bulletin of the United States National Museum, 8: 88 pages.

1908. Reports on the Mollusca and Brachiopods (Albatross Dredging Operations in the Western Pacific). Bulletin of the Museum of Comparative Zoology at Harvard University, 43(6):205-487, 19 plates.

1919. New Shells from the North-West Coast. Proceedings of the Biological Society of Washington, 32:249-251.

1920. Annotated List of the Recent Brachiopoda in the Collection of the United States National Museum, with Descriptions of Thirty-Three New Forms. Proceedings of the United States National Museum, 57: 261-377. 
Davidson, $\mathrm{T}$.

1855. A Few Remarks on the Brachiopoda. Annals and Magazine of Natural History, series 2, 16:429-442.

1870. On Italian Tertiary Brachiopoda. Geological Magazine, 7:359-370, 399-408, 460-466, plates 17-21.

1880. Report on the Brachiopoda Dredged by H.M.S. Challenger during the Years 1873-1876. In Report of Scientific Results of the Challenger Expedition (Zoology), 1: 67 pages, 4 plates.

1886-1888. A Monograph of Recent Brachiopoda. Transactions of the Linnaean Society of London, series 2 (Zoology), 4: 248 pages, plates 1-30.

Deslongchamps, Eudes E.

1884. Etude critique sur les brachiopodes nouveau ou peu connus. Bulletin de la Société Linnéenne de Normandie, Caen, series 2, 8:77-213.

Douvillé, $\mathrm{H}$.

1879-1880. Sur quelques genres de brachiopodes Terebratulidae et Waldheimiidae. Société Géologique de France, Bulletin, series 3, 7:251-277.

Duméril, A.M.C.

1806. Zoologie analytique ou méthode naturelle de classification des animaux. 344 pages. Paris: Allais.

Elliott, G. F.

1958. An Abnormal Lophophore in Macandrevia (Brachiopoda). Publications from the Biological Station, Espegrend, 2(21): 5 pages. Universitetet i Bergen.

Fischer P., and D. P. Oehlert

1890a. Diagnoses de nouveaux brachiopodes. Journal de Conchyliologie, series 3, 38(1):70-74.

1890b. Brachiopodes provenant des campagnes de L'Hirondelle. Bulletin Société Zoologique de France: 15: 118-121.

1891. Brachiopodes. In Expedition scuentifique du Travailleur el du Talisman (1880-1883). 139 pages, 8 plates. Paris.

1892. Résultals de Campagnes scientifíques accomplis sur son yacht (l'Hirondelle) par Albert ler, Prince Souverain de Monaco, 3: Brachiopodes de l'Atlantique Nord. 30 pages, 2 plates.

Forbes, E.

1844. Report on the Mollusca and Radiata of the Aegean Sea, and on Their Distribution, Considered as Bearing on Geology. In British Association Report for 1843: 130-193.

Foster, M. W.

1974. Recent Antarctic and Subantarctic Brachiopods. Antarctic Research Series, 21: 189 pages, 25 plates. Washington, D.C.: American Geophysical Union.

Friele, $\mathrm{M}$.

1877. The Development of the Skeleton in the Genus Waldheimia. Archiv for Malhematik Naturvidskab, 2: 380-386.
Gmelin, J. F.

1792. Systema Nalurae. Edition 13, 888 pages. Leipzig.

Gray, J. E.

1840. Synopsis of the Contents of the British Museum. 42nd edition, 370 pages. London.

1848. On the Arrangement of the Brachiopoda. Annals and Magazine of Natural History, series 2, 2:435-440.

1851. Mollusca, part 7: List of British Mollusca, Acephala, and Brachiopoda. 167 pages. London: British Museum (Natural History).

1853. Catalogue of the Bivalve Mollusca in the Collection, part 4: Brachiopoda, Ancylopoda or Lamp Shells. 128 pages. London: British Museum (Natural History).

Hancock, A.

1858. On the Organization of the Brachiopoda. Philosophical Transactions of the Royal Society, 148(2):791869 , plates $52-66$.

Helmcke, J. G.

1939. Brachiopoda. In W. Kükenthal and T. Krumbach, editors, Handbuch der Zoologte, 3(2): 139-258. Berlin.

1940. Die Brachiopoden der Deutschen Tiefsee Expedition. In Wissenschaftliche Ergebnisse Deutschen TiefseeExpedition auf dem Dampfer "Valdivia" 1898-1899, 24(3):217-316, 43 figures.

Hertlein, L. G., and U. S. Grant, IV.

1944. The Cenozoic Brachiopoda of Western North America. Publication of the Untversity of California at Los Angeles in Mathematical and Physical Sciences, 3: 236 pages, 21 plates.

d'Hondt, Jean-Loup

1976. Sur quelques brachiopodes actuel (Océan Atlantique, Mediterranée, Kerguelen). Bulletin du $\mathrm{Mu}$ séum National D'Histoire Naturelle, series 3(350), Zoologie 243: 13 pages, 4 figures.

Huxley, T. H.

1869. An Introduction to the Classification of Animals. 17 pages, 47 figures. London: Churchill and Sons.

Jeffreys, J. G.

1869. The Deep-Sea Dredging Expedition in H.M.S. Porcupine, 1: Natural History. Nature (London), $1(2): 136$.

1876. On Some New and Remarkable North-Atlantic Brachiopoda. Annals and Magazine of Natural History, series 4, 18:250-253.

1878. On the Mollusca Procured during the Lightning and Porcupine Expeditions, 1868-70. Proceedings of the Zoological Society of London, 1:393-416, plates 22, 23.

1880. The French Deep-Sea Exploration in the Bay of Biscay in the Travailleur. In Report of the British Association for 1880:378-390.

Joubin, M. L.

1907. Note sur les brachiopodes recueilles au cours des derniéres croisiéres du Prince de Monaco. Bulletin 
Institut Océanographie (Foundation Albert $I^{\mathrm{er}}$, Prince de Monaco, 103:1-9.

King, W.

1850. A Monograph of the Permian Fossils of England. Palaeontographical Society Monograph, 3: 259 pages, 29 plates.

1859. On Guynia, Dielasma and Macandrevia, Three New Genera of Palliobranchiata Mollusca, One of Which Has Been Dredged in Strangford Lough. Proceedings of the Dublin University Zoological, Botanical Association, 1(3):256-262.

1868. On Some Palliobranchiate Shells from the Irish Atlantic. Proceedings of the Natural History Society of Dublin, 5:170-173.

Kuhn, O.

1949. Lehrbuch der Paläozoologie. 325 pages, 244 figures. Stuttgart: E. Schweizerbart.

Lamarck, J.B.P.A. de M. de

1801. Systéme des animaux sans vertèbres, ou tableau général des classes, des ordres, et des genres de ces animaux dans le Muséum Nationale d'Historie Naturelle. 432 pages. Paris.

1819. Histoire naturelle des animaux sans verlèbres. Volume 3, part 1, 343 pages. Paris: A. Berlin.

Laubier, L., and M. Sibujet

1977. Résultats des campagnes à la mer: Campagnes Biogas, 3 Août - 4 Novembre 1974. Publications du Centre National pour L'Exploration des Océans, 11: 10 pages.

Leach, W. E.

1852. A Synopsis of the Mollusca of Great Britain Arranged According to Their Natural Affinities and Anatomical Structure. 376 pages, 13 plates. London.

Linné, Carl von [Linnaeus carolus]

1758. Systema Naturae. 10th edition, 824 pages.

1767. Systema Naturae. 12th edition, 1154 pages. Stockholm.

Lovén, $\mathrm{S}$.

1846. Index Molluscorum litora Scandinaviae occidentalia habitantium. 50 pages. Stockholm.

Menke, C. T.

1828. Synopsis methodica molluscorum generum omnium et specierum earum quae in Museo Menkeano adservantur. 91 pages. Pyrmonte.

Megerle von Mühlfeldt, J.C.M.

1811. Entwurf eines neuen Systems der Schaltiergehäuse. Magazin Gesellschaft Naturforschende Freunde zu Berlin, 5:38-72.

Müller, O. F.

1776. Zoologiae danicae prodromus seu animalium daniae et Novegiae indigenarum characteres, nomina, et synonyma imprimis popularium. 282 pages. Havniae.

Muir-Wood, H. M.

1955. A History of the Classification of the Phylum Brachiopoda.
124 pages. London: British Museum (Natural History).

1959. Report on the Brachiopoda of the John Murray Expedition. In The John Murray Expedition 193334, Science Reports, 10(6):283-317, 5 plates.

Oehlert, D. P.

1887. Brachiopodes. In P. Fischer, Manuel de Conchyliologie et de Paléontologie Conchyliologique, ou Histoire Naturelle des Mollusques vivants et fossiles, 11:1189-1334.

Orbigny, A. d'

1847. Sur les Brachiopodes ou Palliobranches. Comptes Rendus de l'Académie de Science de Paris, 25(5):193195; (7):266-269.

Philippi, R. A.

1836 1844. Enumeratio Molluscorum Siciliae. Volume 1, 267 pages, 12 plates. Berlin.

Poli, J. X.

1795. Testacea utriusque Siciliae eorumque historia naturalis el anatome. 223 pages. Parma.

Reeve, L. A.

1860-1861. Terebralula. In Conchologia Iconica, or Illustrations of the Shells of Molluscous Animals. Volume 13. London.

Retzius, A. J.

1781. Crania oder Todtenkopfs - Muschel. Schriften der Berlin Gesellschafi Naturforschende Freunde, 2:66-76, plate 1.

Risso, A.

1826. Histoire nalurelle des principales Productions de l'Europe Méridionale, el particuliérment de celles des environs de Nice et des Alpes Maritimes, 4: Apercu sur l'Histoire Naturelles des mollusques et des coquilles de l'Europe Méridionale. 439 pages, 12 plates. Paris.

Rowell, A. J., and A. J. Rundle

1967. Lophophore of the Eocene Brachiopod Terebralulina wardensis Elliott. University of Kansas Paleontological Contributions, 15: 8 pages, 1 plate.

Sars, G. O.

1878. Bidrag zu Kundskaben om Norges arkliske Fauna, I: Mollusca Regionis Arcticae Norvegiae. 466 pages, 52 plates, 1 map. Christiania.

Scacchi, A.

1833. Osservazioni Zoologiche. Number 2, 27 pages. Napoli.

Scacchi, A., and R. A. Philippi

1844. Enumeratio Molluscorum Siciliae. Volume 2, 303 pages, plates 13-28.

Schuchert, C., and C. M. LeVene

1929. Fossilium Catalogus, 1: Animalia, part 42: Brachiopoda. 140 pages. Berlin: W. Junk.

Sowerby, G. B.

1846, 1847. The Recent Brachiopoda. In Thesaurus Conchylionum, parts 6, 7:221-406, plates 67-73. London. 


\section{Steinich, G.}

1963. Drei neue Brachiopoden-gattungen der Subfamilie Cancellothyrinae Thomson. Geologie, 12(6): 732-740.

1965. Die Artikulaten Brachiopoden der Rügener Schreibkreide (Unter-Maastricht). Paläontologische Abhandlungen, Paläozoologie, 2(1): 220 pages, 21 plates.

Thomson, J. A.

1918. Brachiopoda. In Australasian Antarctic Expedition, 1911-1914, Scientific Reports (Zoology and Botany), $4(3)$ : 76 pages, plates $15-18$, map.

1926. A Revision of the Subfamilies of the Terebratulidae (Brachiopods). Annals and Magazine of Natural History, series 9, 18:523-530.

1927. Brachiopod Morphology and Genera (Recent and Tertiary). New Zealand Board of Science and Art, Manual, 7: 338 pages, 103 figures, 2 plates.
Waagen, W. H.

1882 [1885]. Salt Range Fossils, part 4 (2): Brachiopoda. Palaeontologia Indica, Memoir, series 13, 1(2):391770, plates 25-86 [(2):391-546, plates 29-49, August 1883 ; (5):729-770, plates $82-86$, July 1885$]$.

Williams, A., et al.

1965. Brachiopoda. In R. C. Moore, editor, Treatise on Invertebrate Paleontology, part H, 927 pages, 746 figures. Lawrence, Kansas: University of Kansas Press.

Zezina, O. N.

1965. The Distribution of the Deep Water Brachiopod Species, Pelagodiscus atlanticus (King). Okeanologiya, 5(2):345-358.

1970. On the Distribution of Brachiopods in the Recent Ocean with Some Reference to the Problem of Zoogeographical Zonation. Palaentological Zhurnal, 2:3-17. 
Plates 


\section{PLATE 1}

Figures 1-8.-Eucalathis ergastica Fischer and Oehlert: 1-4, Anterior, dorsal, side, and ventral views of adult, $\times 5$, hypotype MNHN-BRA-78-35 (Thalassa 73, Z409, at 1035-1080 meters).

5 , Interior of old dorsal valve, $\times 5$, showing much thickened loop, hypotype MNHN-BRA78-36; 6, spicular loop from preceding, $\times 5$ (Thalassa 73, Z393, at 750 meters).

7,8 , Interior of ventral and dorsal valves of specimen younger than preceding, $\times 5$, showing characteristic loop, hypotype MNHN-BRA-78-42 (Thalassa 73, Z435, at 1050 meters).

Figures 9-12.-Eucalathis tuberata (Jeffreys): Side, anterior, ventral, and dorsal views of specimen showing frayed pedicle and fine ornament, hypotype MNHN-BRA-78-37;9, 12, at $\times 6 ; 10$, 11 , at $\times 5$ (Thalassa $73, \mathrm{Z} 410$, at 1180 meters).

Figures 13-21.- Terebratulina retusa emarginata (Risso): 13, Dorsal view of complete adult specimen, $\times 2$, showing frayed pedicle, hypotype MNHN-BRA-78-38a; 20, interior of dorsal valve of another specimen, $\times 2$ showing adult loop in form of a ring, hypotype MNHNBRA-78-38b; 21, spicular skeleton of lophophore of preceding dorsal valve, $\times 3$ (all from Biogas I, DS 01, at 310 meters).

14,15 , Dorsal views of two immature individuals, $\times 5$, showing strongly beaded costellae and wide foramen of young, hypotypes MNHN-BRA-78-39a,b;18, 19, interior of two immature dorsal valves showing loop with transverse band incomplete and just completed at anterior, $\times 5$, hypotypes MNHN-BRA-78-39c,d (all from Thalassa 73, Z398, at 330 meters).

16 , A very young specimen, $\times 5$, showing elongate outline, hypotype MNHN-BRA-78-40 (Thalassa 73, Z393 at 390 meters).

17, Interior of very young dorsal valve, showing descending lamellae of loop just forming, $\times 5$, hypotype MNHN-BRA-78-43 (Thalassa 73, Z397, at 511 meters).

Figures 22-25.-Cryptopora gnomon Jeffreys 22-24, Dorsal, side, and ventral views of complete specimen, $\times 5$, hypotype MNHN-BRA-78-41;25, preceding specimen opened to show dental plates and median septum, $\times 5$ (Biogas V, KR 45, at 2864 meters).

Figure 26.-Crania anomala turbinata (Poli): Dorsal view of young specimen attached to same pebble as specimen of Macandrevia cranium (Müller), $\times 1.5$, hypotype MNHN-BRA-78-44 (Biogas I DS 01, at 310 meters).

Figure 27-30.-Gryphus vitreus (Born): 27-29, Anterior, side, and dorsal views, of typical specimen, $\times 1$, showing small foramen, and rectimarginate anterior commissure, hypotype MNHN-BRA-78-45a; 30, posterior of interior of dorsal valve, $\times 2$, showing short loop with flattened hinge plates and slender crura, hypotype MNHN-BRA-78-45b (all from Biogas I, DS 01 , at 310 meters).

Figure 31-38.-Hispanirhynchia cornea (Fisher): 31-33, Anterior, side, and dorsal views, $\times 1$, of large and wide specimen, hypotype MNHN-BRA-78-46a; 34, posterior of preceding, $\times 3$, showing beak, foramen, and deltidial plates; 35 , exterior of part of dorsal valve, $\times 5$, showing capillate surface (all from Biogas III, CV 22, at 1331 meters).

36,37 , Ventral and side views of interior of dorsal valve, $\times 2$, showing short, median septum and spinulifer crura, hypotype MNHN-BRA-78-47a; 38, posterior of preceding enlarged, $\times 3$, to show details of hinge plates and crura (Biogas II, GV 21, at 994 meters). 


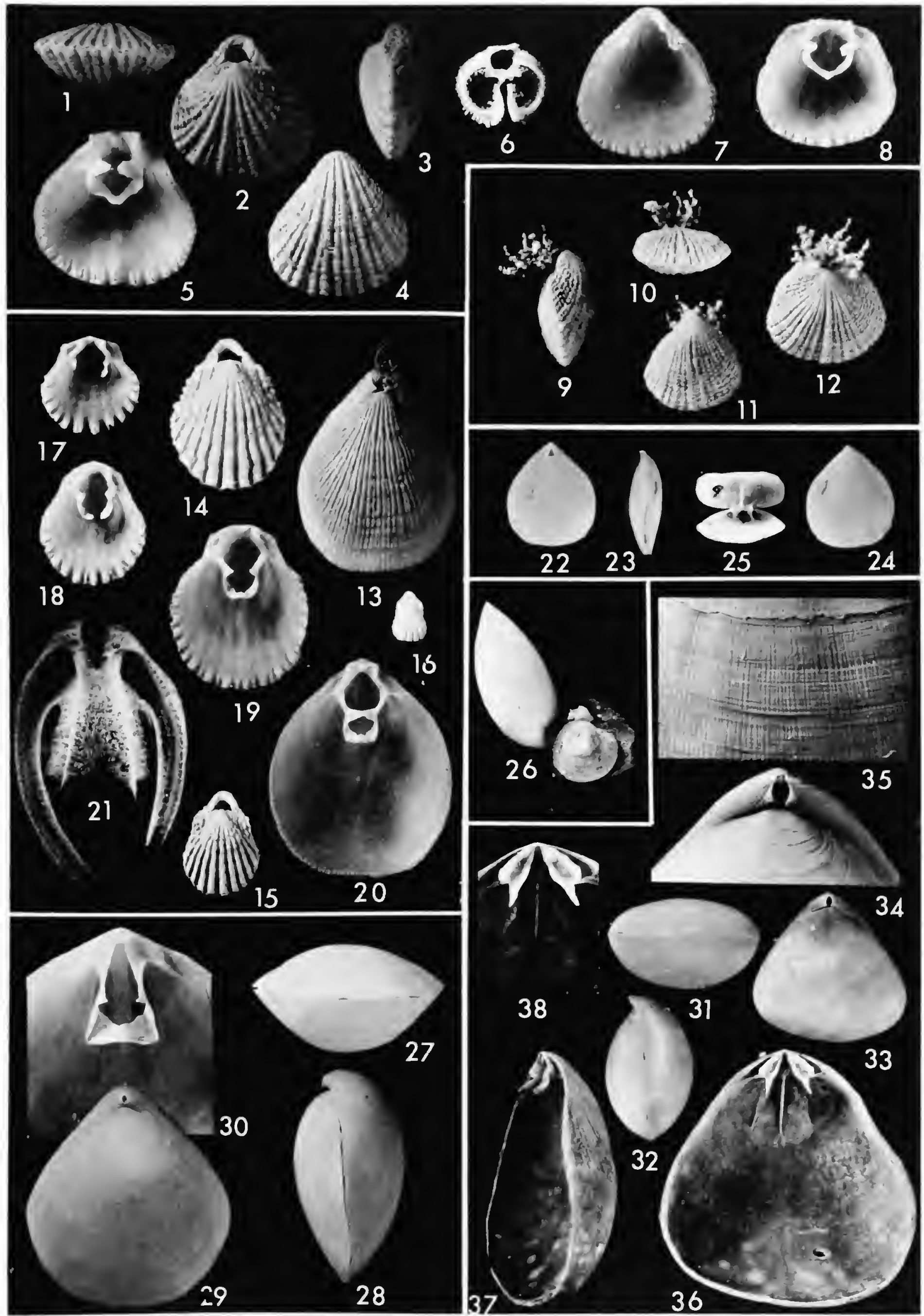




\section{PLATE 2}

Figures 1-17.-Macandrevia novangliae Dall: 1, Dorsal view of holotype, USNM 78069, $\times 2$, (latitude $39^{\circ} 38^{\prime} \mathrm{N}$, longitude $70^{\circ} 22^{\prime} \mathrm{W}$, off New Jersey, United States, at 1837 meters).

2-4, Anterior and dorsal views, $\times 1$, of oval specimen, hypotype MNHN-BRA-48f; 5-7, side, anterior, and dorsal views, $\times 1$, of another specimen rounder than preceding, hypotype MNHN-BRA-78-48d; 8-10, anterior, side, and dorsal views, of round individual, $\times 1$, hypotype MNHN-BRA-78-48a; 11, dorsal view of preceding, $\times 2$, showing unmodified foramen; $12-14$, anterior, side, and dorsal views, $\times 1$, of more posteriorly acute specimen, hypotype MNHN-BRA-78-48b; 15, dorsal view of preceding, $\times 2 ; 16,17$, ventral and side views of interior of hypotype MNHN-BRA-78-48h, showing loop, $\times 2$ (all from Biogas V, CP 07, at 2170 meters).

Figure 18.-Platidia anomioides (Scacchi and Philippi): Dorsal view of exterior of largest specimen, $\times 5$, hypotype MNHN-BRA-78-49 (Thalassa 73, Z435, at 1050 meters).

Figures 19-30.-Macandrevia cranium (Müller): 19-21, Anterior, side, and dorsal views, $\times 1$, of fairly round specimen, hypotype MNHN-BRA-78-50a; 22, 23, anterior and dorsal-views, $\times 1$, of specimen more slender than preceding, hypotype MNHN-BRA-78-50b; 24, preceding specimen, $\times 2$, showing unmodified foramen; 28 , side view of interior of dorsal valve showing the loop, $\times 2$, hypotype MNHN-BRA-78-50c; 30, ventral view of interior of another dorsal valve, $\times 2$, showing free loop and sloping hinge plates, hypotype MNHN-BRA-78-50d (all from Biogas I, DS 01, at 310 meters).

25-27, Side, anterior, and dorsal views, $\times 1$, of specimen larger than preceding ones, hypotype MNHN-BRA-78-51 (Biogas II, CV 21, at 994 meters).

29 , Interior of immature specimen showing loop in early campagiform stage, $\times 9$, hypotype MNHN-BRA-78-52 (Thalassa 73, Z409, at 1080 meters).

Figures 31-35.-Fallax dalliniformis Atkins: 31-34, Side, dorsal, ventral, and anterior views, $\times 1$, of characteristic specimen, hypotype MNHN-BRA-78-53; 35, preceding specimen, $\times 1.5$ showing round foramen (Biogas III, CV 22, at 1331 meters).

Figures 36-38.-Dallithyris? aff. D.? sphenoidea (Jeffreys): Anterior, dorsal, and side views, $\times 1$, of complete specimen, hypotype MNHN-BRA-78-57.

Figures 39, 40.-Pelagodiscus atlanticus (King): Dorsal views of two specimens $\times 5$, showing long setae, hypotypes MNHN-BRA-78-54, -55 (respectively from Biogas IV, DS 57, at 2906 meters, and Biogas VI, CP 17 at, 4706 meters).

Figures 41-43.-Dallina septigera (Lovén): Side, anterior, and dorsal views of large specimen, $\times 1$, hypotype MNHN-BRA-78-56, showing triangular outline, anterior folding, and large foramen (Biogas I, CM 01, at 1010 meters). 


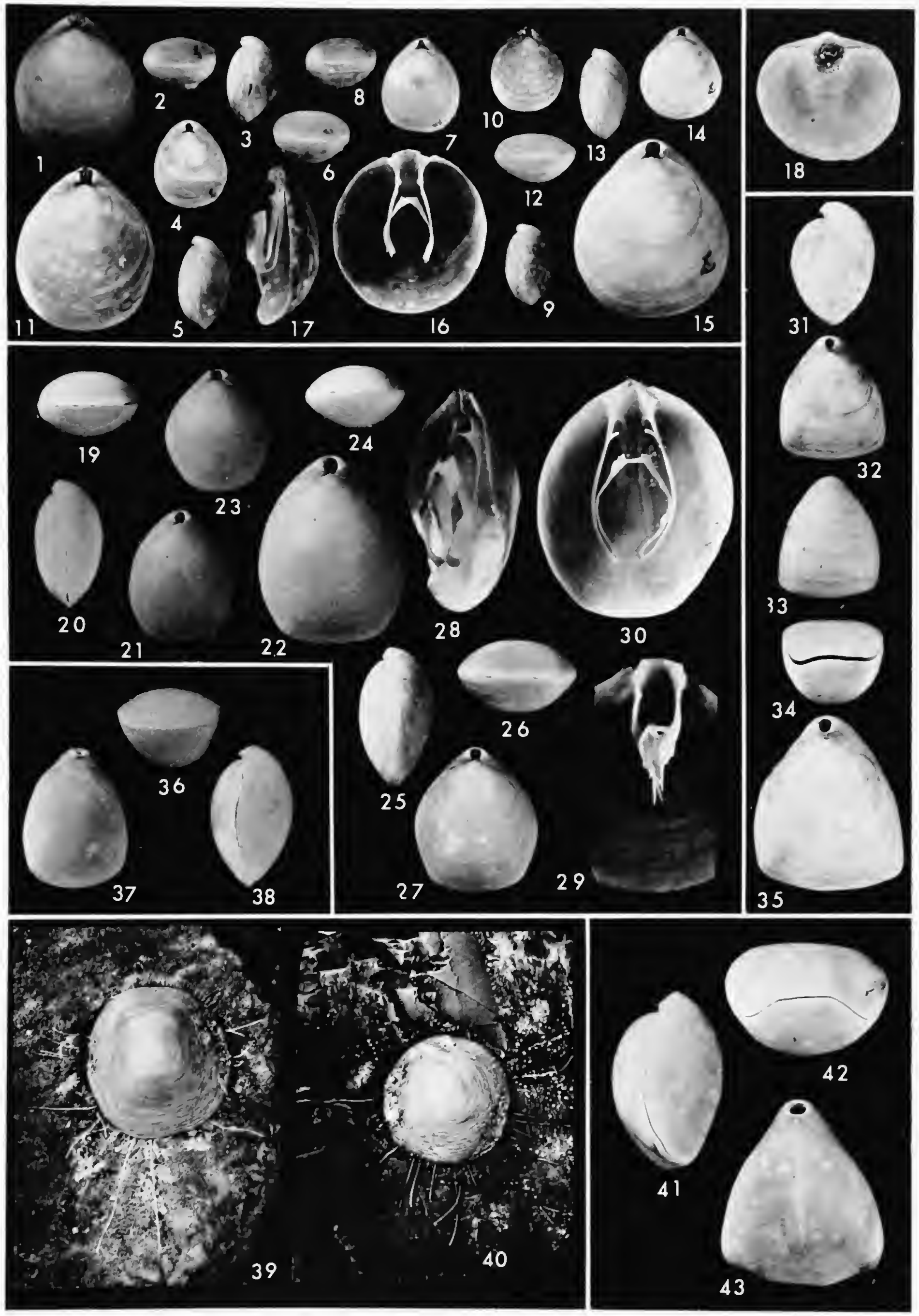




\section{PLATE 3}

Figures 1, 2.-Gryphus? cooperi d'Hondt: 1, Interior of dorsal valve, $\times 5$, showing loop with its anterodorsally projecting transverse band, hypotype MNHN-BRA-78-11; 2, exterior of ventral valve of preceding specimen, $\times 5$, showing strong concentric growth undulations and faint radii (Thalassa $71, \times 352$, at $580-545 \mathrm{~m}$ ).

Figures 3, 4.-Megerlia echinata (Fischer and Oehlert): Dorsal and ventral views, $\times 5$, of young individual, hypotype MNHN-BRA-78-58 (Thalassa 70, W355, at $1000 \mathrm{~m}$ ).

Figures 5-11.-Megerlia truncala (Linné): 5, Dorsal view of average specimen, $\times 1$, hypotype MNHN-BRA-78-59a; 6-9, dorsal, anterior, side, and ventral views, $\times 2$, of preceding specimen, showing sulcate anterior commissure; 11, exterior of part of preceding specimen showing costellae and small spines, $\times 3 ; 10$, interior of dorsal valve, $\times 2$, showing cardinalia and median septum, hypotype MNHN-BRA-78-59b (Thalassa 70, W368, at 400-137 m).

Figures 12-14.-Crania anomala (Müller): 12, Exterior of a dorsal valve, $\times 1$, hypotype MNHNBRA-78-60; 13, 14, side and dorsal views, $\times 2$, of preceding specimen (Thalassa 70, W368, at $400-137 \mathrm{~m})$.

Figure 15.-Eucalathis tuberata (Jeffreys): Interior of dorsal valve, $\times 4$, showing cardinalia and damaged loop, hypotype MNHN-BRA-78-61 (Thalassa 71, ×348, at 900-600 m).

Figures 16-18.-Pantellaria monstruosa (Scacchi): Anterior, dorsal, and ventral views $\times 2$, of characteristically distorted specimen, hypotype MNHN-BRA-78-62 (Thalassa 71, ×352, at $580-545 \mathrm{~m})$.

Figures 19-36.-Dallina parva, new species: 19, Dorsal view of complete specimen, $\times 1$, holotype MNHN-BRA-78-63b; 20-23, dorsal, ventral, anterior, and side views, $\times 3$, of holotype; 24, dorsal view, $\times 1$, of another complete specimen, paratype MNHN-BRA-78-63a; 25-28, ventral, side, dorsal, and anterior views, $\times 3$ of preceding paratype; 29-31, side, partial side, and ventral views of specimen with complete but young loop attached to median septum, paratype MNHN-BRA-78-63d; 32, 33, ventral views of two dorsal valve interiors, $\times 4$, second showing loop with attachment to median septum partially resorbed and first with loop still attached to the median septum, paratypes MNHN-BRA-78-63g,h; 34, interior of the ventral valve without dental plates, $\times 4$, paratype MNHN-BRA-78-63e; 35, ventral view of young specimen, $\times 3$, showing descending branches of loop attached to median septum, paratype MNHN-BRA-78-63f; 36, side view, $\times 5$, of specimen showing complete loop freed from median septum by resorption of lateral bands, paratype MNHN-BRA-78-63i (Thalassa $71, \times 352$, at $580-545 \mathrm{~m})$. 


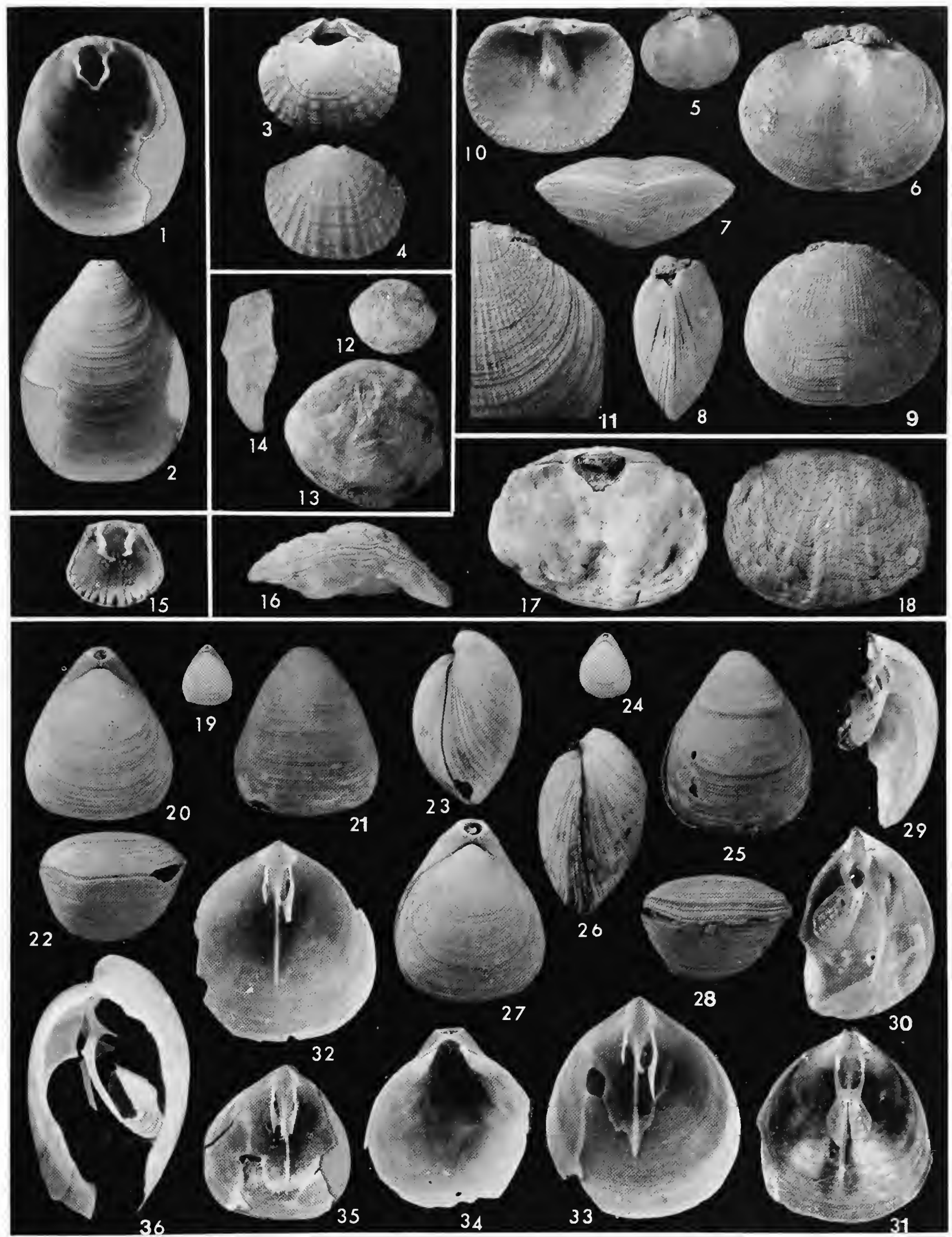





\section{REQUIREMENTS FOR SMITHSONIAN SERIES PUBLICATION}

Manuscripts intended for series publication receive substantive review within their originating Smithsonian museums or offices and are submitted to the Smithsonian Institution Press with approval of the appropriate museum authority on Form Si-36. Requests for special treatment-use of color, foldouts, casebound covers, etc.-require, on the same form, the added approval of designated committees or museum directors.

Review of manuscripts and art by the Press for requirements of series format and style, completeness and clarity of copy, and arrangement of all material, as outlined below, will govern, within the judgment of the Press, acceptance or rejection of the manuscripts and art.

Copy must be typewritten, double-spaced, on one side of standard white bond paper, with $11 / 4$ " margins, submitted as ribbon copy (not carbon or xerox), in loose sheets (not stapled or bound), and accompanied by original art. Minimum acceptable length is 30 pages.

Front matter (preceding the text) should include: title page with only title and author and no other information, abstract page with author/title/series/etc., following the established format, table of contents with indents reflecting the heads and structure of the paper.

First page of text should carry the title and author at the top of the page and an unnum. bered footnote at the bottom consisting of author's name and professional mailing address.

Center heads of whatever level should be typed with initial caps of major words, with extra space above and below the head, but with no other preparation (such as all caps or underline). Run-in paragraph heads should use period/dashes or colons as necessary.

Tabulations within text (lists of data, often in parallel columns) can be typed on the text page where they occur, but they should not contain rules or formal, numbered table heads.

Formal tables (numbered, with table heads, boxheads, stubs, rules) should be submitted as camera copy, but the author must contact the series section of the Press for editorial attention and preparation assistance before final typing of this matter.

Taxonomic keys in natural history papers should use the alined-couplet form in the zoology and paleobiology series and the multi-level indent form in the botany series. If cross-referencing is required between key and text, do not include page references within the key, but number the keyed-out taxa with their corresponding heads in the text.

Synonymy in the zoology and paleobiology series must use the short form (taxon, author, year:page), with a full reference at the end of the paper under "Literature Cited." For the botany series, the long form (taxon, author, abbreviated journal or book title, volume, page, year, with no reference in the "Literature Cited") is optional.

Footnotes, when few in number, whether annotative or bibliographic, should be typed at the bottom of the text page on which the reference occurs. Extensive notes must appear at the end of the text in a notes section. If bibliographic footnotes are required, use the short form (author/brief title/page) with the full reference in the bibliography.

Text-reference system (author/year/page within the text, with the full reference in a "Literature Cited" at the end of the text) must be used in place of bibliographic footnotes in all scientific series and is strongly recommended in the history and technology series: "(Jones, 1910:122)" or ".. . . Jones (1910:122)."

Bibliography, depending upon use, is termed "References," "Selected References," or "Literature Cited." Spell out book, journal, and article titles, using initial caps in all major words. For capitalization of titles in foreign languages, follow the national practice of each language. Underline (for italics) book and journal titles. Use the colon-parentheses system for volume/number/page citations: "10(2):5-9." For alinement and arrangement of elements, follow the format of the series for which the manuscript is intended.

Legends for illustrations must not be attached to the art nor included within the text but must be submitted at the end of the manuscript - with as many legends typed, doublespaced, to a page as convenient.

Illustrations must not be included within the manuscript but must be submitted sepa. rately as original art (not copies). All illustrations (photographs, line drawings, maps, etc.) can be intermixed throughout the printed text. They should be termed Figures and should be numbered consecutively. If several "figures" are treated as components of a single larger figure, they should be designated by lowercase italic letters (underlined in copy) on the illus. tration, in the legend, and in text references: "Figure 9ㅁ.." If illustrations are intended to be printed separately on coated stock following the text, they should be termed Plates and any components should be lettered as in figures: "Plate 9b." Keys to any symbols within an illustration should appear on the art and not in the legend.

A few points of style: (1) Do not use periods after such abbreviations as " $\mathrm{mm}$, $\mathrm{ft}$, yds, USNM, NNE, AM, BC." (2) Use hyphens in spelled-out fractions: "two-thirds." (3) Spell out numbers "one" through "nine" in expository text, but use numerals in all other cases if possible. (4) Use the metric system of measurement, where possible, instead of the English system. (5) Use the decimal system, where possible, in place of fractions. (6) Use day/month/year sequence for dates: "9 April 1976." (7) For months in tabular list. ings or data sections, use three-letter abbreviations with no periods: "Jan, Mar, Jun," etc.

Arrange and paginate sequentially EVERY sheet of manuscript-including ALL front matter and ALL legends, etc., at the back of the text-in the following order: (1) title page, (2) abstract, (3) table of contents, (4) foreword and/or preface, (5) text, (6) appendixes, (7) notes, (8) glossary, (9) bibliography, (10) index, (11) legends. 


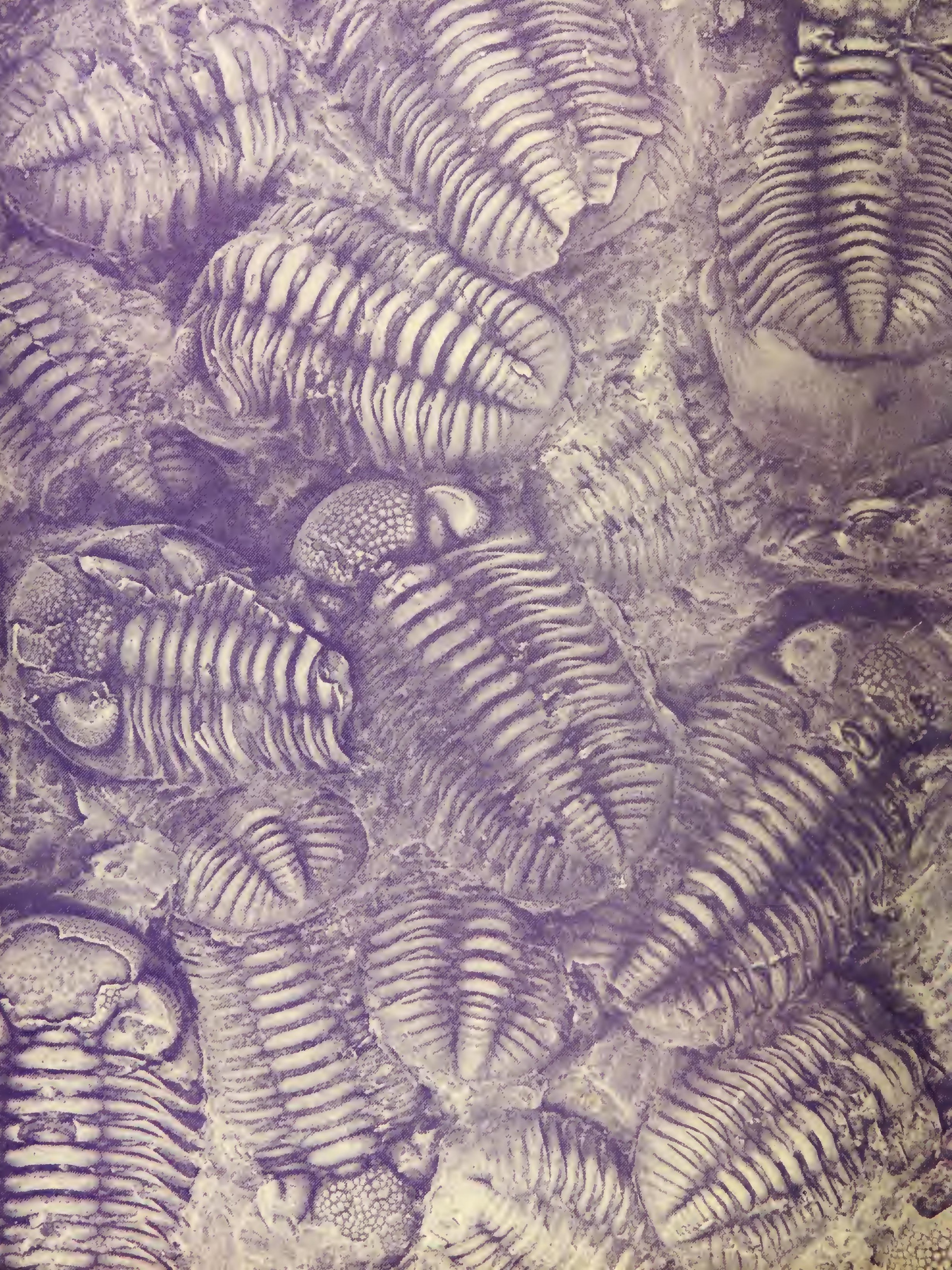

